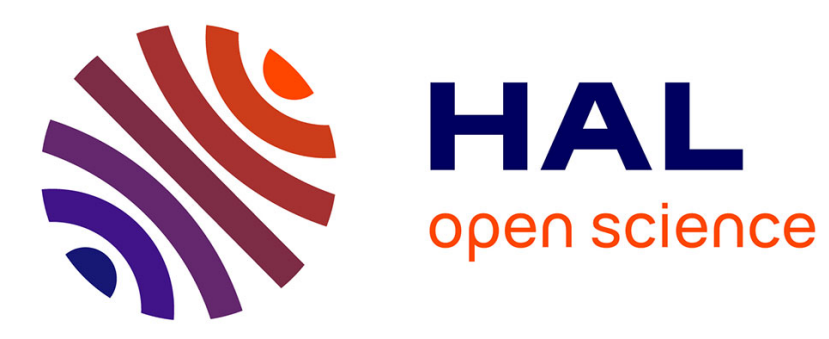

\title{
Microsized Sn as Advanced Anodes in Glyme-Based Electrolyte for Na-Ion Batteries
}

Biao Zhang, Gwenaëlle Rousse, Dominique Foix, Romain Dugas, Daniel Alves

Dalla Corte, Jean-marie Tarascon

\section{- To cite this version:}

Biao Zhang, Gwenaëlle Rousse, Dominique Foix, Romain Dugas, Daniel Alves Dalla Corte, et al.. Microsized Sn as Advanced Anodes in Glyme-Based Electrolyte for Na-Ion Batteries. Advanced Materials, 2016, 10.1002/adma.201603212 . hal-01382712

\section{HAL Id: hal-01382712 \\ https: / hal.sorbonne-universite.fr/hal-01382712}

Submitted on 17 Oct 2016

HAL is a multi-disciplinary open access archive for the deposit and dissemination of scientific research documents, whether they are published or not. The documents may come from teaching and research institutions in France or abroad, or from public or private research centers.
L'archive ouverte pluridisciplinaire HAL, est destinée au dépôt et à la diffusion de documents scientifiques de niveau recherche, publiés ou non, émanant des établissements d'enseignement et de recherche français ou étrangers, des laboratoires publics ou privés. 


\section{Submitted to \\ ADANCEDS
MATERRALIS}

\section{Article type: Communication}

\section{Microsized Sn as advanced anodes in glyme-based electrolyte for Na-ion batteries}

Biao Zhang, Gwenaëlle Rousse, Dominique Foix, Romain Dugas, Daniel Alves Dalla Corte and Jean-Marie Tarascon*

Dr. B. Zhang, Prof. G. Rousse, Dr. D. Foix, Dr. R. Dugas, Dr. D. Alves Dalla Corte, Prof. J.M. Tarascon

Chimie du Solide-Energie, UMR 8260, Collège de France, 11 Place Marcelin Berthelot, 75231 Paris Cedex 05, France

E-mail: jean-marie.tarascon@ college-de-france.fr

Dr. B. Zhang, Prof. G. Rousse, Dr. D. Foix, Dr. R. Dugas, Dr. D. Alves Dalla Corte, Prof. J.M. Tarascon

Réseau sur le Stockage Electrochimique de l'Energie (RS2E), FR CNRS 3459, 80039

Amiens, France

Dr. B. Zhang, Prof. G. Rousse, Dr. D. Foix, Dr. R. Dugas, Dr. D. Alves Dalla Corte, Prof. J.M. Tarascon

ALISTORE-European Research Institute, 80039 Amiens, France

Prof. G. Rousse, Prof. J.M. Tarascon

Sorbonne Universités - UPMC Univ Paris 06, 4 place Jussieu, F-75005 Paris, France.

Dr. D. Foix

IPREM/ECP (UMR 5254), University of Pau, 2 av. Pierre Angot, 64053 Pau cedex 9,France

Keywords: Tin, electrolyte, microsize, Na ion battery 
Submitted to

The concept of Na-ion batteries was proposed in 1980s but was abandoned later due to its lower energy density than Li-ion batteries. The revival of Na-ion technology in recent years relies on the low cost and natural abundance of Na sources, which will bring a roughly $30 \%$ decrease in the cost compared to Li-ion batteries, albeit at $\sim 15 \%$ penalty of energy density currently ${ }^{[1]}$. Thanks to intensive studies carried out in the past several years, researchers have been able to develop several high performance cathode materials for $\mathrm{Na}$-ion batteries which are structurally close to the ones successfully developed for Li-ion batteries. Polyanionic $\mathrm{Na}_{3} \mathrm{~V}_{2}\left(\mathrm{PO}_{4}\right)_{2} \mathrm{~F}_{3},{ }^{[2]} \mathrm{Na}_{3} \mathrm{~V}_{2}\left(\mathrm{PO}_{4}\right)_{3},{ }^{[3,4]}$ layered P2-type $\mathrm{Na}_{2 / 3}\left(\mathrm{Fe}_{1 / 2} \mathrm{Mn}_{1 / 2}\right) \mathrm{O}_{2}{ }^{[5]}$ and prussian white $\mathrm{Na}_{1.92} \mathrm{Fe}\left[\mathrm{Fe}(\mathrm{CN})_{6}\right]^{[6]}$ deliver energy densities close to those presently obtained in Li-ion batteries. Turning to the anodes, hard carbon is considered as one of the most promising candidates. $^{[7,8]}$ However, it has a low reversible capacity of around $250 \mathrm{mAh} / \mathrm{g}$ with a relatively high potential of $\sim 0.28 \mathrm{~V}$ vs $\mathrm{Na}$ in average, i.e. showing a poorer behavior than graphite anode in Li-ion battery. Developing high performance anodes are urgently required for Na-ion batteries in order to catch up the energy density of Li-ion batteries. At this stage, research efforts are devoted to two directions: one is aiming at increasing the capacity and decreasing the average potential of hard carbon by tailoring its microstructure, ${ }^{[9-12]}$ while considerable work are also conducted on searching for new candidates among which alloy anodes are most attractive.

Alloy anodes, including $\mathrm{Sn},{ }^{[13]} \mathrm{Sb}{ }^{[14]}$ and $\mathrm{Pb}^{[15]}$ have been widely studied due to their high capacities, yet the mild toxicity of $\mathrm{Sb}$ and $\mathrm{Pb}$ makes them less promising for practical applications. In contrast, $\mathrm{Sn}$ is an environmental friendly material and abundant in nature. The commercialization of Li-ion batteries based on Sn-Co alloys as negative electrodes was even considered. ${ }^{[16]}$ Moreover, Sn has a high theoretical capacity of $847 \mathrm{mAh} / \mathrm{g}$ through the formation of $\mathrm{Na}_{15} \mathrm{Sn}_{4}$ alloys. ${ }^{[17]}$ Coupling with aforementioned cathode, such as $\mathrm{Na}_{2 / 3}\left(\mathrm{Fe}_{1 / 2} \mathrm{Mn}_{1 / 2}\right) \mathrm{O}_{2}$, it is possible to build a Na-ion battery exhibiting an energy density close to the one of classic Li-ion battery. ${ }^{[18]}$ The main issue that prevents the commercialization of 
volume change of around $420 \%$ during $\mathrm{Sn}$ is the fast capacity fading arising from the large volume change of around $420 \%$ during cycling. ${ }^{[19,20]}$ Extensive studies have been put on fabrication of $\mathrm{Sn} / \mathrm{C}$ composites, which have greatly improved the cyclic stability by maintaining the electrode integrity. ${ }^{[21-23]}$ A drawback of these nanostructured materials is their low density that will lead to a low volumetric energy density for batteries. Moreover, large irreversible capacity is observed in the $1^{\text {st }}$ cycle due to the solid electrolyte interface (SEI) formation on the high surface area of nanosized materials. Therefore, microsized Sn particles with stable cycling stability are eagerly expected in view of practical application. Instead of preparing nanoparticles, herein we report the highly stable bulk $\mathrm{Sn}$ anodes through the use of glyme-based electrolyte so as to achieve both high gravimetric and volumetric energy densities.

Microsized Sn particle (325 mesh) was used directly as active materials. It was ballmilled with 20wt.\% Carbon SP for 30 mins. The short time ball milling did not reduce much the particle size: the particles remain $5-50 \mu \mathrm{m}$ as revealed by scanning electron microscopy (SEM). Carbon SP are attached on the surface of Sn to establish a fast electron transfer path in the electrode (Figure S1). The mixture was then dispersed in a carboxymethylcellulose sodium (CMC) aqueous solution, which was coated on a $\mathrm{Cu}$ foil and dried under vacuum before being transferred into Ar glove box. The electrochemical performances were evaluated in coin cells with $\mathrm{Na}$ metal as both reference and counter electrodes. Carbonate-based electrolytes have been successfully commercialized in Li-ion batteries, and similar systems are currently widely explored for Na-ion batteries. Several typical protocols including ethylene carbonate (EC)/dimethyl carbonate (DMC), EC/diethyl carbonate (DEC) and propylene carbonate (PC) as solvents with $1 \mathrm{M} \mathrm{NaPF}_{6}$ or $\mathrm{NaClO}_{4}$ as salts have been reported. ${ }^{[24]}$ Since Sn particles have catalytic effects on the decomposition of EC, ${ }^{[25]}$ here battery tests were firstly performed in $1 \mathrm{M} \mathrm{NaPF}_{6}$ in $\mathrm{PC}$ electrolytes. $5 \%$ fluoroethylene carbonate (FEC) is used as additives to stabilize $\mathrm{Na}$ metal and also help to establish a stable SEI. ${ }^{[26]}$ Around 2.7 $\mathrm{Na}$ could be alloyed with $\mathrm{Sn}$ in the first reduction, corresponding to a capacity of $617 \mathrm{mAh} / \mathrm{g}$. 


\section{Submitted to

However, the capacity degrades quickly down to only $300 \mathrm{mAh} / \mathrm{g}$ in the first 10 cycles and further reduces to below $100 \mathrm{mAh} / \mathrm{g}$ after 20 cycles (Figure S2a,b). This observation is not surprising considering the huge volume change of $\mathrm{Sn}$ during Na-Sn alloy process. ${ }^{\text {[27] }}$ The repeating sodiation and de-sodiation results in the disconnection of $\mathrm{Sn}$ particles in the electrode, as revealed by the fracturing of the cycled electrodes observed by SEM (Figure S3). Insulating active materials from current collector gives rise to the loss of Sn activity and therefore a fast capacity fade.

To combat this issue several approaches have been previously tried. Among them is the confinement of nanosized Sn particles in conductive carbon phases which offer additional free space for volume change, but also bring issues of low density and high irreversible capacity. Another one deals with the development of efficient binders such as poly(acrylic acid), ${ }^{[28]}$ and poly (9,9-dioctylfluorene-co-fluorenone-co-methylbenzoic ester) (PFM) ${ }^{[29]}$ to constrain the nanosized Sn particles so that stable capacity retention up to 20 cycles was achieved. Owing to their limited successes, we decided to explore different electrolyte formulations in our search for a potential solution for the long cyclic stability of microsized Sn. Glyme-based electrolyte have been reported for graphite anodes in Na-ion battery to enable the cointercalation of solvated $\mathrm{Na},{ }^{[30,31]}$ and for improving the cyclic stability of conversion anodes. ${ }^{[32]}$ Similar system is applied here to check the performance in Sn alloy anode. 1M $\mathrm{NaPF}_{6}$ in diethylene glycol dimethyl ether (diglyme, DGME) was used as electrolyte to compare with carbonate-based electrolyte systems. As shown in the Figure 1a, $3.83 \mathrm{Na}$ is involved in the first reduction which is slightly higher than theoretical value due to the $\mathrm{Na}$ consumption in SEI formation. During the following reduction, $3.54 \mathrm{Na}$ is removed corresponding to a Coulombic efficiency of $92 \%$. This value is much higher than the value of $\sim 70 \%$ previously reported for nanostructured $\mathrm{Sn} / \mathrm{C}$ composites. ${ }^{[21-23]}$ Using microsized $\mathrm{Sn}$ greatly reduces the contact area between electrolyte and active materials and thus improves the Coulombic efficiency. The carbon additive also contributes to the Coulombic efficiency 


\section{Submitted to

increase since the irreversible capacity of carbon SP additive is only of $8 \%$ in DGME electrolyte as compared to $63 \%$ in PC/FEC (Figure S4).

Once the first charge is achieved, the following cycles present an increasing Coulombic efficiency and achieve a value of more than $99 \%$ starting from 5 th cycle. Their voltage profiles resemble the one in the first cycle but with a gradual capacity decrease in the initial 10 cycles. Nevertheless, the capacity becomes stable afterwards and the electrodes deliver a capacity as high as $768 \mathrm{mAh} / \mathrm{g}$ after 100 cycles, corresponding to a capacity retention of $88 \%$ (Figure 1b). The cell also shows a good power rate as shown in the inset of Figure 1a. Increasing the cycling rate from $0.1 \mathrm{C}$ to $1 \mathrm{C}$ only slightly decreases the capacity. A high capacity of $622 \mathrm{mAh} / \mathrm{g}$ could be obtained even under a current density of $2 \mathrm{C}$ (equal to 1.69 $\mathrm{A} / \mathrm{g}$ ), proving that the electrode could sustain respectable rate capabilities. Last but not least, we should mention that the profile of the $V=f(x)$ curve shows numerous plateaus which are more prominent on charge than on discharge and associated to phase changes. Therefore, somewhat unusual are the artifacts preceding these plateaus, namely on charge where we observe a voltage overshooting which is present once the material is recharged and that becomes sharper when reaching the last forming phase at the end of the charge process $(\sim$ 0.67V). Such spikes are usually reminiscent of phases whose formation (e.g nucleation/growth process) is kinetically limited. To test this hypothesis we studied the effect of the current density on the amplitude of these peaks. Indeed, increasing the current results in a decrease of the spikes implying that these kinetically limited phases are not any longer forming (Figure S5). To make an analogy, we could say that for less feeling the holes on the road, we must move quickly, because we do not leave time the wheels to penetrate deeply; the holes being the potential well. Similarly, this could explain why the number of plateaus is inferior to the number of phases reported.

To explore the reasons behind the stability of Sn in DGME as compared to PC-based electrolyte, we explored the morphology of electrode by SEM after 100 cycles (insets in 
GME shows a smooth surface, in sharp Figure 1b, and Figure S6). The electrode cycled in DGME shows a smooth surface, in sharp contrast to rough surface observed in the electrode tested in PC. Although some cracks are observed, the integrity of the electrode is mainly preserved without the appearance of isolated particles. A close view into the electrode reveals that the particles are surrounded by thin SEI films, which prevent the separation of the active materials from the matrix. The composition of the films was examined by X-ray photoelectron spectroscopy (XPS), and the deconvoluted $\mathrm{C} 1 \mathrm{~s}, \mathrm{O} 1 \mathrm{~s}$ and F1s spectra for the pristine and cycled electrode are shown in Figure 2. A peak at $283.7 \mathrm{eV}$ from conductive carbon SP is observed in C1s spectra. The peaks at 285, 286.6 and $288.2 \mathrm{eV}$ in the fresh electrode are assigned to $\mathrm{C}-\mathrm{C}(\mathrm{H}), \mathrm{C}-\mathrm{O}$ and $\mathrm{C}-\mathrm{O}_{2}$ species presented in CMC binder. ${ }^{[33]}$ The proportion of $\mathrm{C}-\mathrm{C}(\mathrm{H})$ peak at $285 \mathrm{eV}$ increases prominently after long cycling: an indication of the formation of sodium alkoxides $\left(\mathrm{RCH}_{2} \mathrm{ONa}\right)$ groups as a result of reduction of DGME. ${ }^{[34]}$ Note also the appearance of another peak at $290 \mathrm{eV}$ corresponding to the formation of $\mathrm{Na}_{2} \mathrm{CO}_{3}$. This assignment is confirmed by the O1s spectra which shows the growth of a carbonate specie peak at $531 \mathrm{eV} \cdot{ }^{[35]}$ Moreover, a comparison of the O1s spectra before and after cycling (Figure $2 \mathrm{~b}$ ) suggests the formation of $\mathrm{NaOH}$ and $\mathrm{Na}_{2} \mathrm{O}$. Turning to the F1s spectrum it shows upon cycling the emergence of two peaks at 684 and $687 \mathrm{eV}$ corresponding to NaF and P-F species, respectively. They can simply be ascribed to the reduction of $\mathrm{NaPF}_{6}$ salts in the electrolyte, emphasizing the role of salts in formation of protecting film. ${ }^{[34]}$

Overall, from the above analysis, the SEI films consist of both organic $\left(\mathrm{RCH}_{2} \mathrm{ONa}\right)$ and inorganic $\left(\mathrm{NaF}, \mathrm{NaPF}_{6}, \mathrm{Na}_{2} \mathrm{O}, \mathrm{Na}_{2} \mathrm{CO}_{3}\right.$ and phosphates) components. For comparative purposes the composition of SEI formed in PC electrolyte was also investigated (Figure S7). The SEI is made of similar species but in different relative proportions suggesting that the SEI growing process is different in both cases. A possible reason could be nested in the high solubility of the sodium oxides and carbonates in $\mathrm{PC}^{[36]}$ due to the mild Lewis acid character of Na. This could result in the formation of less dense SEI films in PC-based electrolytes as 


\section{Submitted to

observed previously by SEM. Although we could not accurately quantify the absolute amounts of some species because of interferences with $\mathrm{CMC}$, this study highlights the importance of building a continuous and dense SEI for improving the cyclic performance of alloy anodes, where glyme-based electrolytes show great advantages.

The family of glyme solvents includes several other members with variation in molecule's chain lengths, including dimethoxyethane (monoglyme, DME) and tetraethylene glycol dimethyl ether (tetraglyme, TGME). Using both DME and DGME solvents give similar capacities, but the utilization of TGME results in a decrease of the reversible capacities to $523 \mathrm{mAh} / \mathrm{g}$ after 50 cycles (Figure S8). This difference may simply be rooted in their ionic conductivity which decreases with the ether chain length due to a greater capturing of the $\mathrm{Na}^{+}$ions, hence leading to a lower mobility. Nevertheless, the change from DGME to DME and TGME does not affect much the stability. Sn electrode preserves the stable cyclic performance in the electrolyte of both $1 \mathrm{M} \mathrm{NaPF}_{6} / \mathrm{DME}$ and $1 \mathrm{M} \mathrm{NaPF} / \mathrm{TGME}$, confirming the benefits of moving from carbonate to glyme solvents for Sn anodes.

The voltage-composition profile for the Sn electrode shows a cascade-like behavior with several plateaus indicating the complexity of the electrochemical reactivity of $\mathrm{Sn}$ against $\mathrm{Na}$ that enlists a multi-steps process. Previous studies by density functional theory (DFT) calculations ${ }^{[19]}$ suggest the existence of a few intermediate phases including $\mathrm{NaSn}_{5}, \mathrm{NaSn}$ and $\mathrm{Na}_{9} \mathrm{Sn}_{4}$ prior to reach the fully sodiated $\mathrm{Na}_{15} \mathrm{Sn}_{4}$. Except $\mathrm{Na}_{15} \mathrm{Sn}_{4}$, however, none of the other phases that are observed during electrochemical alloying in carbonate electrolyte agree with the known equilibrium ones. ${ }^{[17]}$

To figure out the phase transitions in glyme-based electrolyte, in situ X-ray diffraction (XRD) measurements were performed in a Swagelok type cell equipped with a Be window and XRD patterns were collected for every 0.25 Na change (Figure 3a). The phase changes in DGME are similar to what was reported in carbonate electrolyte, suggesting that the electrolyte does not have any impact on the structural aspect of the Na alloying-dealloying 


\section{ADNANEDS
MATERRALS}

process with $\mathrm{Sn}$. Numerous $\mathrm{Na}_{\mathrm{x}} \mathrm{Sn}$ phases do exist, but identifying their exact composition from in situ XRD measurements is not trivial because of $\mathrm{Na}$ consumption associated to the SEI formation which introduces inaccuracy on the $\mathrm{Na}$ content. To address this issue, we decided, in light of our recent work, to chemically prepare these alloys by reactive Na-ball milling. ${ }^{[37]}$ Several $\mathrm{Na}_{\mathrm{x}} \mathrm{Sn}$ compositions were tried. For $\mathrm{x}<1$ we could not, alike electrochemical measurements, stabilize any single phase materials. In contrast powders made of the reported $\mathrm{Na}_{0.2} \mathrm{Sn}$ or $\sim \mathrm{Na}_{0.5} \mathrm{Sn}$ phases and remaining $\mathrm{Sn}$ were always obtained. The use of longer ball milling times lead to the amorphisation of the $\mathrm{Na}_{\mathrm{x}} \mathrm{Sn}$ while not affecting the amount of Sn secondary phase. We then focused on the synthesis of $\mathrm{Na}$ rich $\mathrm{Na}_{\mathrm{x}} \mathrm{Sn}$ alloys with $x \geq 1$ and successfully prepared the $\mathrm{NaSn}, \mathrm{Na}_{9} \mathrm{Sn}_{4}$ and $\mathrm{Na}_{15} \mathrm{Sn}_{4}$ compositions as single phases (Figure 3).

It is worthwhile mentioning that pure and nicely crystallized NaSn phase (Figure S9) having an orthorhombic structure could also be obtained by annealing at $100^{\circ} \mathrm{C}$ for 24 hours the amorphous powder recovered from an electrochemical cell discharged down to $0.11 \mathrm{~V}$ $\left(\mathrm{x}_{\text {elec }} \sim 1.5\right)$. Further pursuing the ball milling experiments with a $\mathrm{Na}$ to $\mathrm{Sn}$ ratio of 2.25 $\left(\mathrm{Na}_{9} \mathrm{Sn}_{4}\right)$, we obtained a crystalline phase with an XRD powder pattern analog to that obtained by discharging a cell down to $0.05 \mathrm{~V}$. However, this pattern differs from the one previously reported for the same composition which crystallizes in the $\mathrm{Cmcm}$ space group, ${ }^{[17]}$ thus we embarked in a depth structural study of this "new polymorph".

The Synchrotron X-ray diffraction pattern of $\mathrm{Na}_{9} \mathrm{Sn}_{4}$ powder prepared by ball-milling is shown in Figure 3c. The measurement was done using a wavelength of $0.4959 \AA$ that corresponds to $25 \mathrm{keV}$, i.e. below the Sn K-edge absorption energy (29.209 keV). The pattern can clearly be not indexed in the previously reported $\mathrm{Cmcm}$ structure, therefore we have here the evidence of a new $\mathrm{Na}_{9} \mathrm{Sn}_{4}$ polymorph. Interestingly, a similar pattern was previously attributed to $\mathrm{Na}_{5} \mathrm{Sn}_{2}$ by comparison with the pattern of $\mathrm{Li}_{5} \mathrm{Sn}_{2}$. ${ }^{[38,39]}$ To the best of our knowledge, this attribution was based on the lattice parameters and similarity in peaks 


\section{Submitted to

intensities for patterns measured below either a Be window or a kapton film, using lab X-ray diffraction. We therefore started from the $\mathrm{Li}_{5} \mathrm{Sn}_{2}$ model to refine our synchrotron data. All $\mathrm{Na}_{9} \mathrm{Sn}_{4}$ peaks can be indexed in a rhombohedral unit cell, space group $R-3 m$, with refined lattice parameters $a=5.43958(2) \AA, c=22.43084(7) \AA$. Our first Rietveld refinements were done with $\mathrm{Na}$ atoms are distributed on three crystallographic sites, $\mathrm{Na} 1$ on the Wyckoff positions $3 b(0,0,1 / 2)$, and $\mathrm{Na} 2$ and $\mathrm{Na} 3$ both on the $6 c$ position $(0,0, \mathrm{z})$, with $\mathrm{z}=0.358$ and $\mathrm{z}=0.208$ for $\mathrm{Na} 2$ and $\mathrm{Na} 3$, respectively. Sn atoms are located on a single $6 c$ position with $\mathrm{z}=$ 0.0637. This structural model corresponds to a chemical formula $\mathrm{Na}_{5} \mathrm{Sn}_{2}$; however refining the refinement showed a huge and unrealistic $B_{\text {iso }}$ temperature factors of $30 \AA^{2}$ for Na1. This indicated that the electronic density is too large on this site. The refinement using this model and imposing identical $\mathrm{B}_{\text {iso }}$ for all $\mathrm{Na}$ atoms is shown in Figure $\mathrm{S} 10$ and presents intensity problems with some reflections with too much intensity (e.g. (012)), while others are too low (eg. (101)). Therefore we refined the occupancy of the Nal atom, still imposing the $\mathrm{B}_{\text {iso }}$ identical for all $\mathrm{Na}$ atoms. This led to a crystallographic occupancy of $0.45(5)$, a value close to the theoretical value 0.5 that would correspond to the $\mathrm{Na}_{9} \mathrm{Sn}_{4}$ chemical formula. Note however that the resulting $\mathrm{B}_{\text {iso }}$ are pretty large, indicating that $\mathrm{Na}$ is highly mobile. The final refinement also took into account an anisotropic strain, with $S_{400}=0.209(6), S_{004}=0.00158(5)$ and $S_{112}=0.125(3)$ according to Stephen's notations. ${ }^{[40]}$ This indicates lattice parameters fluctuations perpendicular to the [001] direction. The final refinement is shown in Figure 3c and is greatly improved compared to the $\mathrm{Na}_{5} \mathrm{Sn}_{2}$ model, and Table $\mathrm{S} 1$ gathers crystallographic information of $\mathrm{Na}_{9} \mathrm{Sn}_{4}$.

Figure $3 \mathrm{c}$ shows the structures of the $\mathrm{Na}_{9} \mathrm{Sn}_{4}$ polymorph reported in the present paper. The structure of previously reported $\mathrm{Na}_{9} \mathrm{Sn}_{4}$ and the one of $\mathrm{Na}_{5} \mathrm{Sn}_{2}\left(\mathrm{Li}_{5} \mathrm{Sn}_{2}\right.$-type structure) are given in Figure S11. The common feature to all structures is that they present Sn-Sn dimers (Sn-Sn distance of $2.85 \AA$ ) all oriented in the same direction, and separated by Na atoms. Our $\mathrm{Na}_{9} \mathrm{Sn}_{4}$ structure presents larger lattice parameters than the $\mathrm{Na}_{5} \mathrm{Sn}_{2}$ structure, especially for the 

may come as a surprise, as our structure presents less Na; most likely this difference comes from electrostatic interactions. The two $\mathrm{Na}_{9} \mathrm{Sn}_{4}$ polymorphs-the rhombohedral one reported in this paper and the orthorhombic $\mathrm{Cmcm}$ structure- differ in the way $\mathrm{Sn}$-Sn dimers are stacked, as highlighted in Figure S11.

For sake of completion we explore the Na-rich end phase and found that both ball milling and electrochemical sodiation can easily lead to the formation of the $\mathrm{Na}_{15} \mathrm{Sn}_{4}$ phase which was refined using the Rietveld method (Figure S12). Note that this $\mathrm{Na}_{15} \mathrm{Sn}_{4}(\mathrm{x}<3.75)$ phase can reversibly be reoxidized via a reacting path enlisting the successive formation of $\mathrm{Na}_{9} \mathrm{Sn}_{4}$, and then NaSn phases (Figure 3a). The Na poor phase of $\mathrm{Na}_{\mathrm{x}} \mathrm{Sn}(\mathrm{x}<1)$ is not seen on charging, and $\mathrm{NaSn}$ is directly transformed into $\mathrm{Sn}$. Nucleation of $\mathrm{Sn}$ from the poorly crystallized NaSn phase leads to voltage oscillations around $0.67 \mathrm{~V}$. The Na-Sn alloy and dealloy processes follow the same traces afterwards, as indicated by identical voltage profiles shown in Figure1a. The lattice parameters of the $\mathrm{Na}_{\mathrm{x}} \mathrm{Sn}$ phases formed during $\mathrm{Na}-\mathrm{Sn}$ alloy are summarized in Figure 4, and the volume at different sodiation stages are calculated. It reveals an almost linear volume expansion along with the increase in the $\mathrm{Na}$ contents. A fully transformation from $\mathrm{Sn}$ to $\mathrm{Na}_{15} \mathrm{Sn}_{4}$ would lead to a $430 \%$ increase in the volume, consistent with previous observation under in situ TEM and by DFT calculations. ${ }^{[19,20]}$ The results shown here offer some implications to rational design of even better Sn-based electrodes for addressing the volume change during cycling.

To test the benefit of $\mathrm{Sn}$ negative electrodes, full Na-ions cells using $\mathrm{Na}_{3} \mathrm{~V}_{2}\left(\mathrm{PO}_{4}\right)_{3}$ (denoted hereafter NVP) as positive electrode and $1 \mathrm{M} \mathrm{NaPF} /$ DGME as electrolyte were assembled. Based on the reversible capacity of NVP vs. Na which equals $90 \mathrm{mAh} / \mathrm{g}$ (Figure S13), Sn/NVP Na-ion cell were assembled with a mass ratio of NVP to Sn of 8.05 and cycled at a rate of $\mathrm{C} / 5$. The cell shows an initial charge capacity of $102 \mathrm{mAh} / \mathrm{g}$ and a discharge capacity of $83 \mathrm{mAh} / \mathrm{g}$ at an average voltage of $3 \mathrm{~V}$ (Figure 5). The irreversible loss is mainly 
Submitted to

due to the Na consumption during the SEI formation at the Sn anode. Otherwise the cell shows a decent capacity retention since it maintains $90 \%$ of the initial capacity after 50 cycles. Further improvements rely on both the optimization of NVP cathode and balancing the ratio of cathode to anode. In the $50^{\text {th }}$ cycle, the cell delivers an energy density of $200 \mathrm{Wh} / \mathrm{kg}$ taking account the mass of active materials in both the cathode and anode. For comparison, we made a NVP/C Na-ion cell using $1 \mathrm{M} \mathrm{NaPF}_{6}$ in $\mathrm{EC} / \mathrm{DMC}$ electrolyte and similar cycling protocol with therefore a mass ratio of NVP to hard carbon is 3 . The NVP/C cell cycled between 3.8$1.5 \mathrm{~V}$ shows an average voltage of $3.1 \mathrm{~V}$ (Figure S13c). A capacity of $72 \mathrm{mAh} / \mathrm{g}(\mathrm{NVP})$ is obtained in the $50^{\text {th }}$ cycle, giving an energy density of $168 \mathrm{Wh} / \mathrm{kg}$ calculated based on the total mass of NVP and hard carbon. This highlight the benefit of using Sn as anode since a $19 \%$ improvement in gravimetric energy density is obtained when compared to NVP/C cells (Figure 5b). The volumetric energy densities were calculated using the theoretic density of Sn $\left(7.3 \mathrm{~g} / \mathrm{cm}^{3}\right)$, and NVP $\left(3.3 \mathrm{~g} / \mathrm{cm}^{3}\right)$, respectively, and a value of $1.6 \mathrm{~g} / \mathrm{cm}^{3}$ for hard carbon. Thanks to the high density Sn, NVP/Sn shows a volumetric energy density of $703 \mathrm{Wh} / \mathrm{L}, 61 \%$ increase compared to $438 \mathrm{Wh} / \mathrm{L}$ for NVP/C cell.

In summary, we have reported glyme based electrolytes enable high reversible capacity of $\mathrm{Sn}$ anode for Na-ion batteries. The improvement in the stability mainly relies on the formation of protecting films which prevent the formation of insulating domains of active materials. Moreover, the Na-Sn phases during electrochemical alloying are examined through in situ XRD characterization to clarify several intermediate phases such as amorphous NaSn. In particular, a new polymorph of $\mathrm{Na}_{9} \mathrm{Sn}_{4}$ is found and its crystal structure is analyzed by synchrotron X-ray diffraction. Lastly, prototype full cells using Sn anode and NVP cathode are assembled. They demonstrate the great advantages of using Sn instead of hard carbon as anodes since enchantments of $19 \%$ and $61 \%$ increase in gravimetric and volumetric energy densities, respectively, can be achieved. Although the long-term stability and the cost of 


\section{Submitted to

glyme electrolyte requires further evaluation, we anticipate the results presented here will have strong implication in developing Sn based high performance anodes for Na-ion batteries.

\section{Experimental Section}

Preparation of Sn electrode: Commercial Sn particles from Alfa (325 mesh) were used as active materials. Sn and Carbon SP with a mass ratio of four were filled into a hard steel ballmilled jar under Ar. They were ball milled in a Spex 8000M ball-miller with a ball to powder ratio of 10 . The mixture was then mixed with $10 \% \mathrm{CMC}$ binder in de-ionized water, and the resulting slurry was coated in $\mathrm{Cu}$ foil to make a tape. After drying under vacuum at $60^{\circ} \mathrm{C}$, electrodes with diameter of $11 \mathrm{~mm}$ were punched from the tape to assemble coin cells. A typical loading of the active materials in one electrode was $2 \mathrm{mg} / \mathrm{cm}^{2}$. Note that the capacity does not change much when the loading increased to $4 \mathrm{mg} / \mathrm{cm}^{2}$ which delivers similar capacity retention (Figure S14).

Synthesis of $N a_{x} S n$ alloys by ball milling: Stoichiometric amounts of bulk Na metal (Sigma) and Sn powder were filled into the hard steel ball-milled jar in glove box. Stainless steel ball diameter of $12 \mathrm{~mm}$ was used and they were milled in a Spex $8000 \mathrm{M}$ ball miller for $1 \mathrm{~h}$ to obtain $\mathrm{Na}_{\mathrm{x}} \mathrm{Sn}$ loose powder.

Electrochemical tests: Electrolytes are prepared by adding $\mathrm{NaPF}_{6}$ (Stella Chemifa) to various solvents, including PC (BASF), DME, DGME and TGME, to make 1 molar solution. 5wt\% FEC (98\%, Alfa) was added in PC electrolyte. Anhydrous glymes were purchased from Sigma-Aldrich with a purity of more than $99.5 \%$. All the electrolytes were dried by molecular

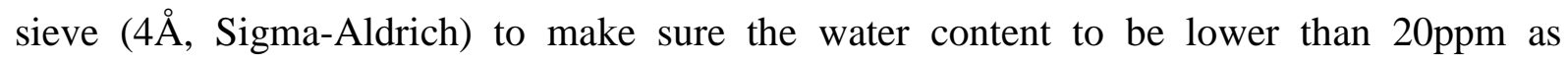
confirmed by Karl-Fisher titration (Metrohm 899 coulometer). The electrochemical performance was examined in coin cells with a piece of glass fiber (Whatman, GF/D) as separator and Na metal as counter electrode. NVP was used a cathode in a full cell to couple with Sn and hard carbon anode. A conventional solid-state reaction was used to prepare NVP according to a previously reported protocol. ${ }^{[41][42]}$ A Swagelok cell was used for in situ XRD 


\section{Submitted to

measurement. Sn/Carbon SP/CMC slurry was coated on the Be window. The cells are galvanostatically cycled in VMP system (Biologic S.A., Claix, France).

Characterizations: XRD patterns were recorded using either a Bruker D8-Advance Diffractometer with $\mathrm{Cu}-\mathrm{K}_{\alpha}$ radiation $\left(\lambda_{1}=1.54056 \AA, \lambda_{2}=1.54439 \AA\right)$ equipped with a LynxEye detector operating at $40 \mathrm{kV}$ and $40 \mathrm{~mA}$. For synchrotron $\mathrm{XRD}$, the powder was placed in a $0.7 \mathrm{~mm}$ diameter capillary, and the pattern was recorded in transmission geometry using a wavelength of $0.4959 \AA$ on the ID22 beamline at ESRF (Grenoble, France). All powder patterns were refined using the Rietveld method ${ }^{[43]}$ as implemented in the FullProf program. ${ }^{[44]}$ Peak shapes were described using a modified Thompson-Cox-Hastings pseudoVoigt function, and the background was modeled with a 12-coeficients Chebyshev polynom. For the synchrotron pattern, absorption was taken into account with $\mu R=0.5$ ( $R$ being the radius of our capillary). For in situ patterns recorded behind a Be window, an absorption correction was applied in the refinements.

The morphology of electrodes after cycling are checked by SEM (Philips, XL30). To prepare the electrodes, the cells are disassembled in the glovebox and washed with DMC and DGME for PC and DGME electrolyte, respectively. XPS measurements were carried out with a Kratos Axis Ultra spectrometer, using a focused monochromatized $\mathrm{Al} \mathrm{K} \alpha$ radiation $(\mathrm{h} v=1486.6 \mathrm{eV})$. The XPS spectrometer was directly connected through a transfer chamber to an argon dry box, in order to avoid moisture/air exposure of the samples. The analysed area of the samples was $300 \times 700 \mu \mathrm{m}^{2}$. Peaks were recorded with a constant pass energy of $20 \mathrm{eV}$. The pressure in the analysis chamber was around $5 \times 10^{-9}$ mbar. Short acquisition time spectra were recorded before and after each normal experiment to check that the samples did not suffer from degradation during the measurements. The binding energy scale was calibrated from the hydrocarbon contamination using the $\mathrm{C} 1 \mathrm{~s}$ peak at $285.0 \mathrm{eV}$. Core peaks were analysed using a nonlinear Shirley-type background. ${ }^{[45]}$ The peak positions and areas were 
optimized by a weighted least-squared fitting method using 70\% Gaussian, 30\% Lorentzian lineshapes.

\section{Supporting Information}

Supporting Information is available online from the Wiley Online Library or from the author.

\section{Acknowledgements}

The RS2E (Réseau sur le Stockage Electrochimique de l'Energie) network is acknowledged for the financial support of this work through the ANR project Storex (ANR-10-LABX-7601). The authors thank Carlotta Giacobbe for the collection of synchrotron X-ray diffraction patterns at European Synchrotron Radiation Facility on ID22, and Renald David for providing $\mathrm{Na}_{3} \mathrm{~V}_{2}\left(\mathrm{PO}_{4}\right)_{3}$.

Received: ((will be filled in by the editorial staff))

Revised: ((will be filled in by the editorial staff)) Published online: ((will be filled in by the editorial staff))

[1] D. Larcher, J. Tarascon, Nat. Chem. 2015, 7, 19.

[2] M. Bianchini, N. Brisset, F. Fauth, F. Weill, E. Elkaim, E. Suard, C. Masquelier, L. Croguennec, Chem. Mater. 2014, 26, 4238.

[3] R. Klee, M. J. Aragón, R. Alcántara, J. L. Tirado, P. Lavela, Eur. J. Inorg. Chem. 2016, Doi:10.1002/ejic.201600241.

[4] C. Zhu, P. Kopold, P. A. van Aken, J. Maier, Y. Yu, Adv. Mater. 2016, 28, 2409.

[5] N. Yabuuchi, M. Kajiyama, J. Iwatate, H. Nishikawa, S. Hitomi, R. Okuyama, R. Usui, Y. Yamada, S. Komaba, Nat. Mater. 2012, 11, 512.

[6] L. Wang, J. Song, R. Qiao, L. A. Wray, M. A. Hossain, Y. De Chuang, W. Yang, Y. Lu, D. Evans, J. J. Lee, S. Vail, X. Zhao, M. Nishijima, S. Kakimoto, J. B. Goodenough, J. Am. Chem. Soc. 2015, 137, 2548.

[7] C. Bommier, T. W. Surta, M. Dolgos, X. Ji, Nano Lett. 2015, 15, 5888.

[8] S. Komaba, W. Murata, T. Ishikawa, N. Yabuuchi, T. Ozeki, T. Nakayama, A. Ogata, K. Gotoh, K. Fujiwara, Adv. Funct. Mater. 2011, 21, 3859.

[9] B. Zhang, C. M. Ghimbeu, C. Laberty, C. Vix-Guterl, J. M. Tarascon, Adv. Energy 
Mater. 2016, 6, 1501588.

[10] G. Hasegawa, K. Kanamori, N. Kannari, J. ichi Ozaki, K. Nakanishi, T. Abe, ChemElectroChem 2015, 2, 1917.

[11] J. Zhang, W. Lv, Y. Tao, Y. B. He, D. W. Wang, C. H. You, B. Li, F. Kang, Q. H. Yang, Energy Storage Mater. 2015, 1, 112.

[12] Y. Li, Y.-S. Hu, H. Li, L. Chen, X. Huang, J. Mater. Chem. A 2015, 4, 96.

[13] Z. Li, J. Ding, D. Mitlin, Acc. Chem. Res. 2015, 48, 1657.

[14] A. Darwiche, C. Marino, M. T. Sougrati, B. Fraisse, L. Stievano, L. Monconduit, J. Am. Chem. Soc. 2012, 134, 20805.

[15] A. Darwiche, R. Dugas, B. Fraisse, L. Monconduit, J. Power Sources 2016, 304, 1.

[16] J. Li, D. B. Le, P. P. Ferguson, J. R. Dahn, Electrochim. Acta 2010, 55, 2991.

[17] L. D. Ellis, T. D. Hatchard, M. N. Obrovac, J. Electrochem. Soc. 2012, 159, A1801.

[18] M. Dahbi, N. Yabuuchi, K. Kubota, K. Tokiwa, S. Komaba, Phys. Chem. Chem. Phys. 2014, 16, 15007.

[19] V. L. Chevrier, G. Ceder, J. Electrochem. Soc. 2011, 158, A1011.

[20] J. W. Wang, X. H. Liu, S. X. Mao, J. Y. Huang, Nano Lett. 2012, 12, 5897.

[21] B. Zhang, J. Huang, J.-K. Kim, Adv. Funct. Mater. 2015, 25, 5222.

[22] Y. Xu, Y. Zhu, Y. Liu, C. Wang, Adv. Energy Mater. 2013, 3, 128.

[23] Y. Liu, N. Zhang, L. Jiao, J. Chen, Adv. Mater. 2015, 27, 6702.

[24] A. Ponrouch, E. Marchante, M. Courty, J.-M. Tarascon, M. R. Palacín, Energy Environ. Sci. 2012, 5, 8572 .

[25] J. S. Bridel, S. Grugeon, S. Laruelle, J. Hassoun, P. Reale, B. Scrosati, J. M. Tarascon, J. Power Sources 2010, 195, 2036.

[26] R. Dugas, B. Zhang, P. Rozier, J. M. Tarascon, J. Electrochem. Soc. 2016, 163, A867.

[27] J. Wang, C. Eng, Y.-C. K. Chen-Wiegart, J. Wang, Nat. Commun. 2015, 6, 7496.

[28] S. Komaba, Y. Matsuura, T. Ishikawa, N. Yabuuchi, W. Murata, S. Kuze, Electrochem. 
commun. 2012, 21, 65 .

[29] K. Dai, H. Zhao, Z. Wang, X. Song, V. Battaglia, G. Liu, J. Power Sources 2014, 263, 276.

[30] B. Jache, P. Adelhelm, Angew. Chemie - Int. Ed. 2014, 53, 10169.

[31] H. Kim, J. Hong, Y.-U. Park, J. Kim, I. Hwang, K. Kang, Adv. Funct. Mater. 2015, 25, 534.

[32] K. Zhang, Z. Hu, X. Liu, Z. Tao, J. Chen, Adv. Mater. 2015, 27, 3305.

[33] D. M. Seo, C. C. Nguyen, B. T. Young, D. R. Heskett, J. C. Woicik, B. L. Lucht, J. Electrochem. Soc. 2015, 162, A7091.

[34] Z. W. Seh, J. Sun, Y. Sun, Y. Cui, ACS Cent. Sci. 2015, 1, 449.

[35] M. A. Munoz-Marquez, M. Zarrabeitia, E. Castillo-Martinez, A. Eguia-Barrio, T. Rojo, M. Casas-Cabanas, ACS Appl. Mater. Interfaces 2015, 7, 7801.

[36] M. Moshkovich, Y. Gofer, D. Aurbach, J. Electrochem. Soc. 2001, 148, E155.

[37] B. Zhang, R. Dugas, G. Rousse, P. Rozier, A. M. Abakumov, J.-M. Tarascon, Nat. Commun. 2016, 7, 10308.

[38] Z. Du, R. A. Dunlap, M. N. Obrovac, J. Alloys Compd. 2014, 617, 271.

[39] L. Baggetto, P. Ganesh, R. P. Meisner, R. R. Unocic, J.-C. Jumas, C. A. Bridges, G. M. Veith, J. Power Sources 2013, 234, 48.

[40] P. Stephens, J. Appl. Crystallogr. 1999, 32, 281.

[41] K. Du, H. Guo, G. Hu, Z. Peng, Y. Cao, J. Power Sources 2013, 223, 284.

[42] F. Lalere, V. Seznec, M. Courty, R. David, J. N. Chotard, C. Masquelier, J. Mater. Chem. A 2015, 3, 16198.

[43] H. M. Rietveld, J. Appl. Crystallogr. 1969, 2, 65.

[44] J. Rodríguez-Carvajal, Physica B 1993, 192, 55.

[45] D. A. Shirley, Phys. Rev. B 1972, 5, 4709. 


\section{Submitted to \\ ADVANCED}
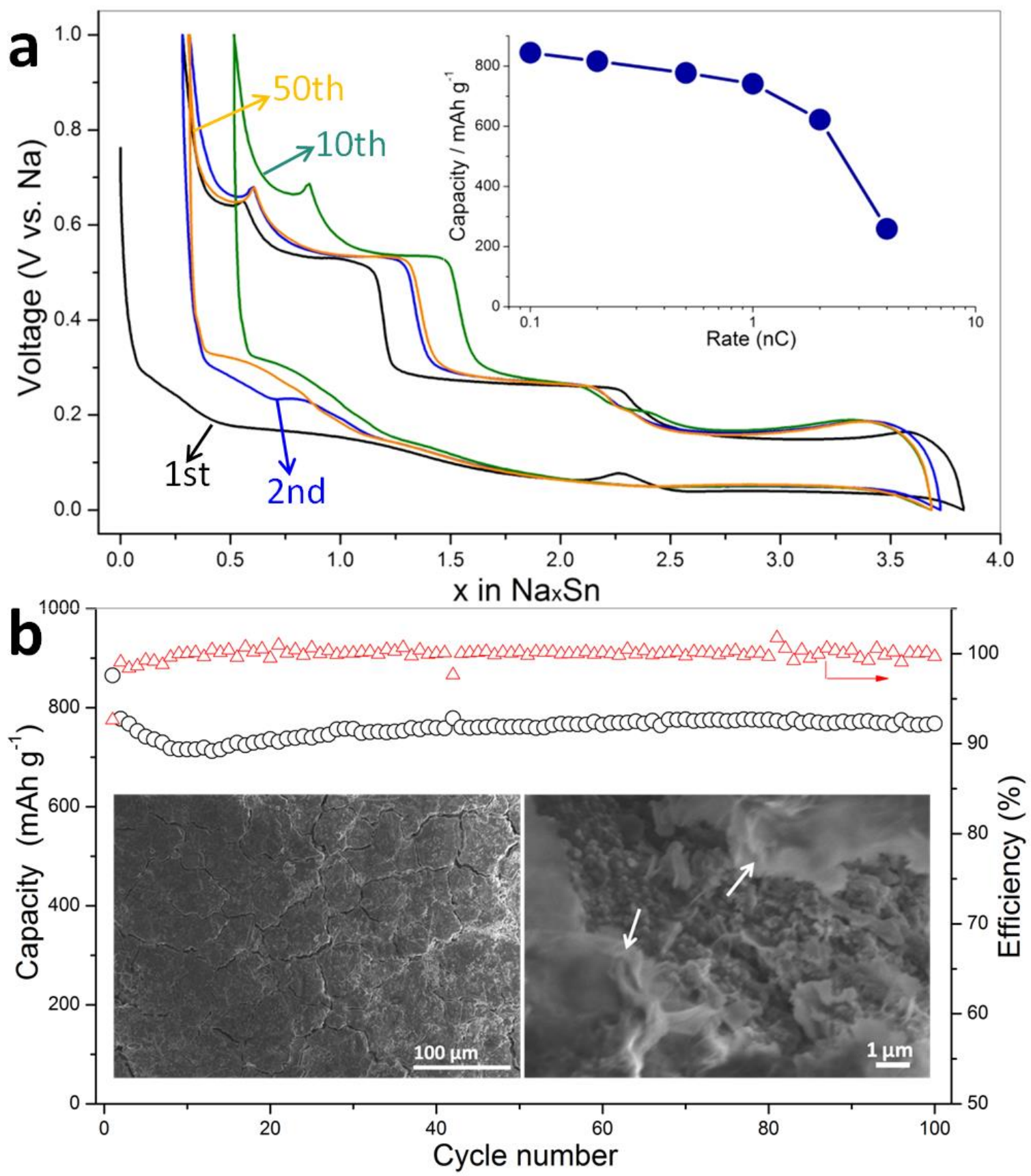

Figure1. Performance of Sn electrode in $1 \mathrm{M} \mathrm{NaPF}_{6} / \mathrm{DGME}$ electrolyte. (a) Voltage profiles with their rate capability (inset), where $1 \mathrm{C}$ equal to $847 \mathrm{~mA} / \mathrm{g}$; (b) cyclic stability at $250 \mathrm{~mA} / \mathrm{g}$. The morphology of the electrodes after 100 cycles is shown in the insets of (b). The arrows indicate SEI films. 


\section{Submitted to
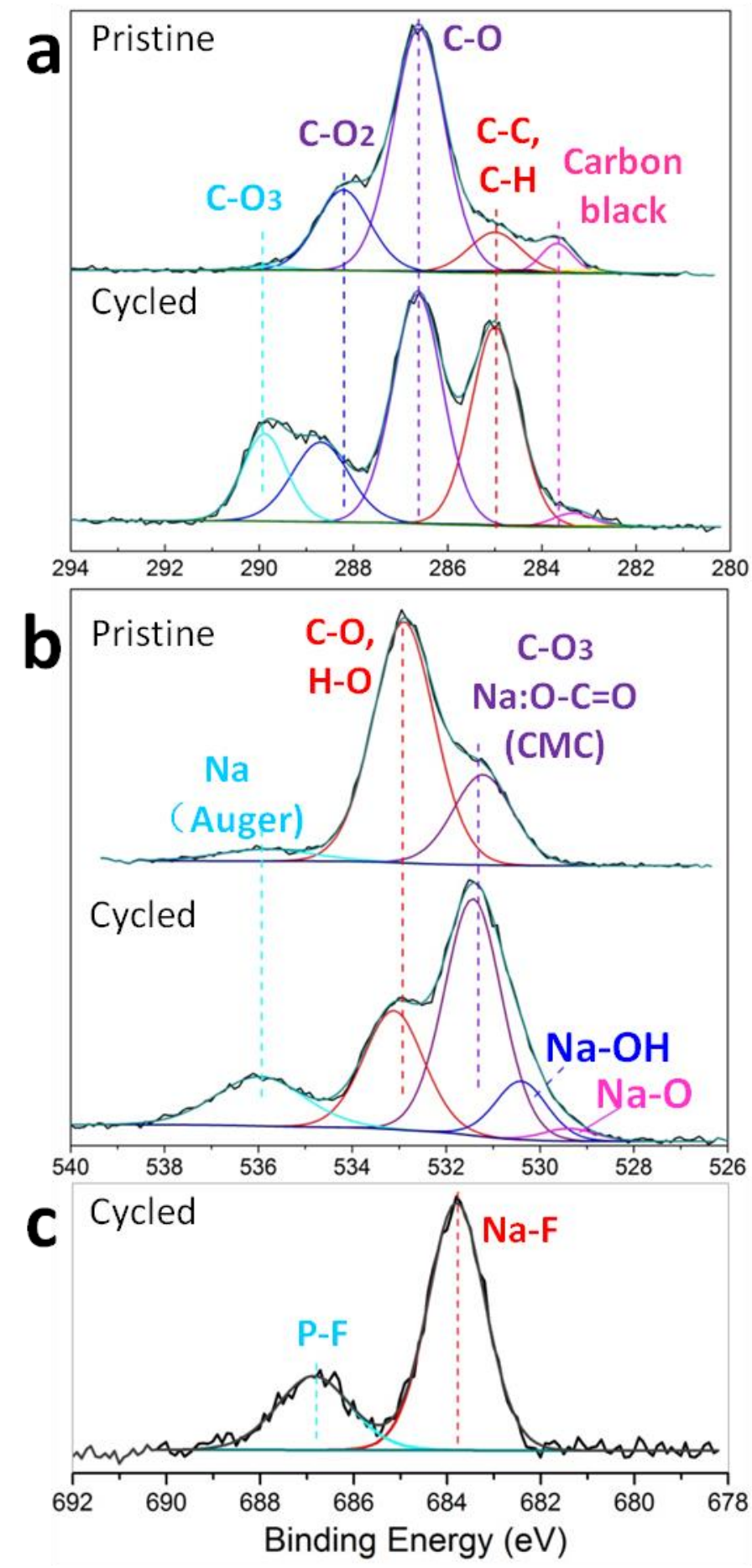

Figure 2. XPS spectra of pristine electrode and after cycling in $1 \mathrm{M} \mathrm{NaPF} / \mathrm{DGME}$ : (a) $\mathrm{C} 1 \mathrm{~s}$;

(b) O1s and (c) F1s. 


\section{Submitted to
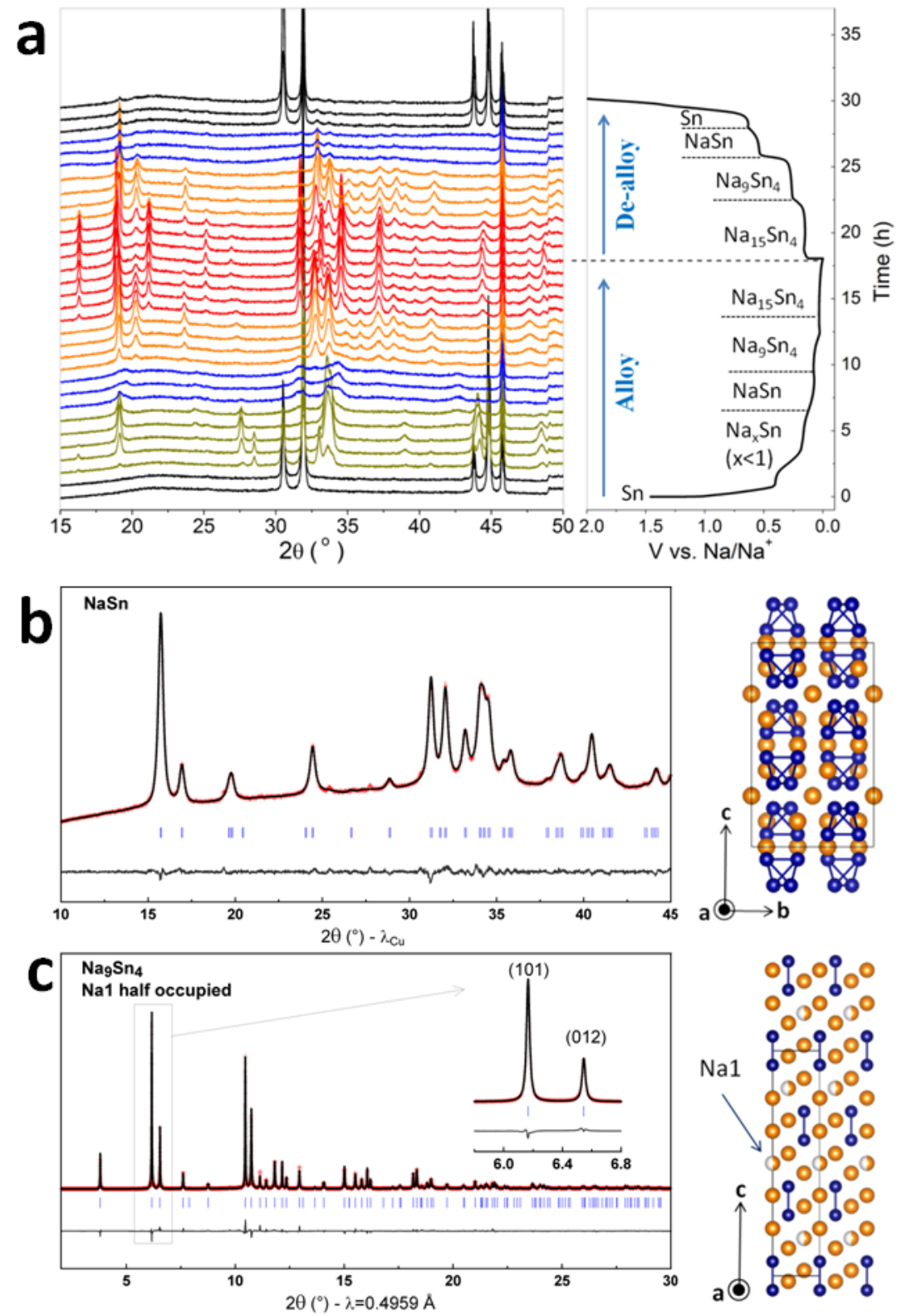

Figure 3. Phase transformation of Sn electrode. (a) In situ XRD patterns during the first cycle; (b) Rietveld refinement of NaSn prepared by ball milling and its crystal structure (right); (c) Rietveld refinement of synchrotron pattern of $\mathrm{Na}_{9} \mathrm{Sn}_{4}$ and its crystal structure (right). The red crosses, black continuous line and bottom gray line represent the observed, calculated, and difference patterns, respectively. Vertical blue tick marks are the Bragg positions. The $\mathrm{Na}$ and $\mathrm{Sn}$ atoms are colored in orange and blue, respectively. The shortest SnSn bonds have been drawn for clarity. 


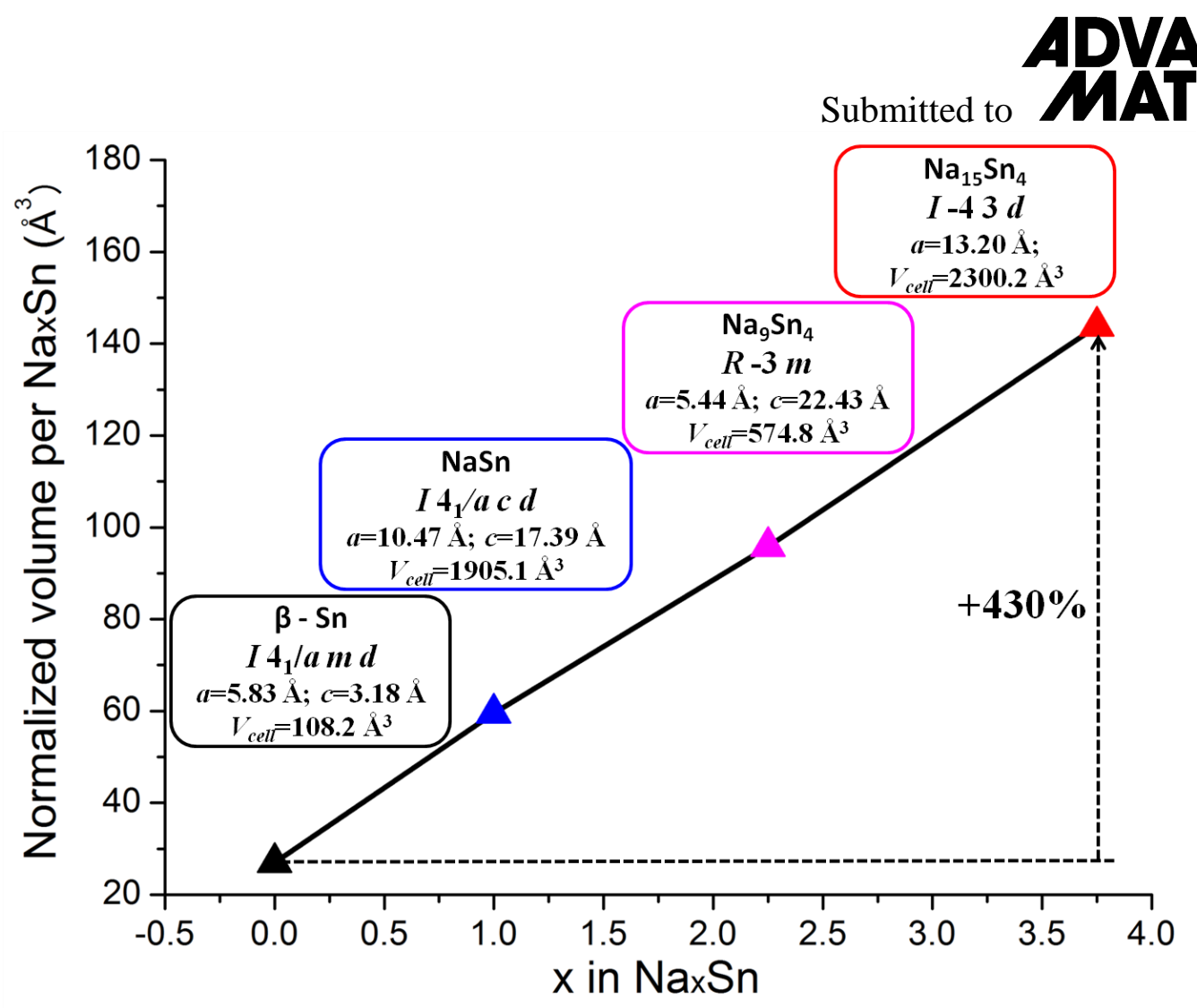

Figure 4. Volume change during Na-Sn alloy. Insets show the crystal structure of the phases, where $\mathrm{V}_{\text {cell }}$ represents the volume of an unit cell. 


\section{Submitted to \\ ADVANCED}
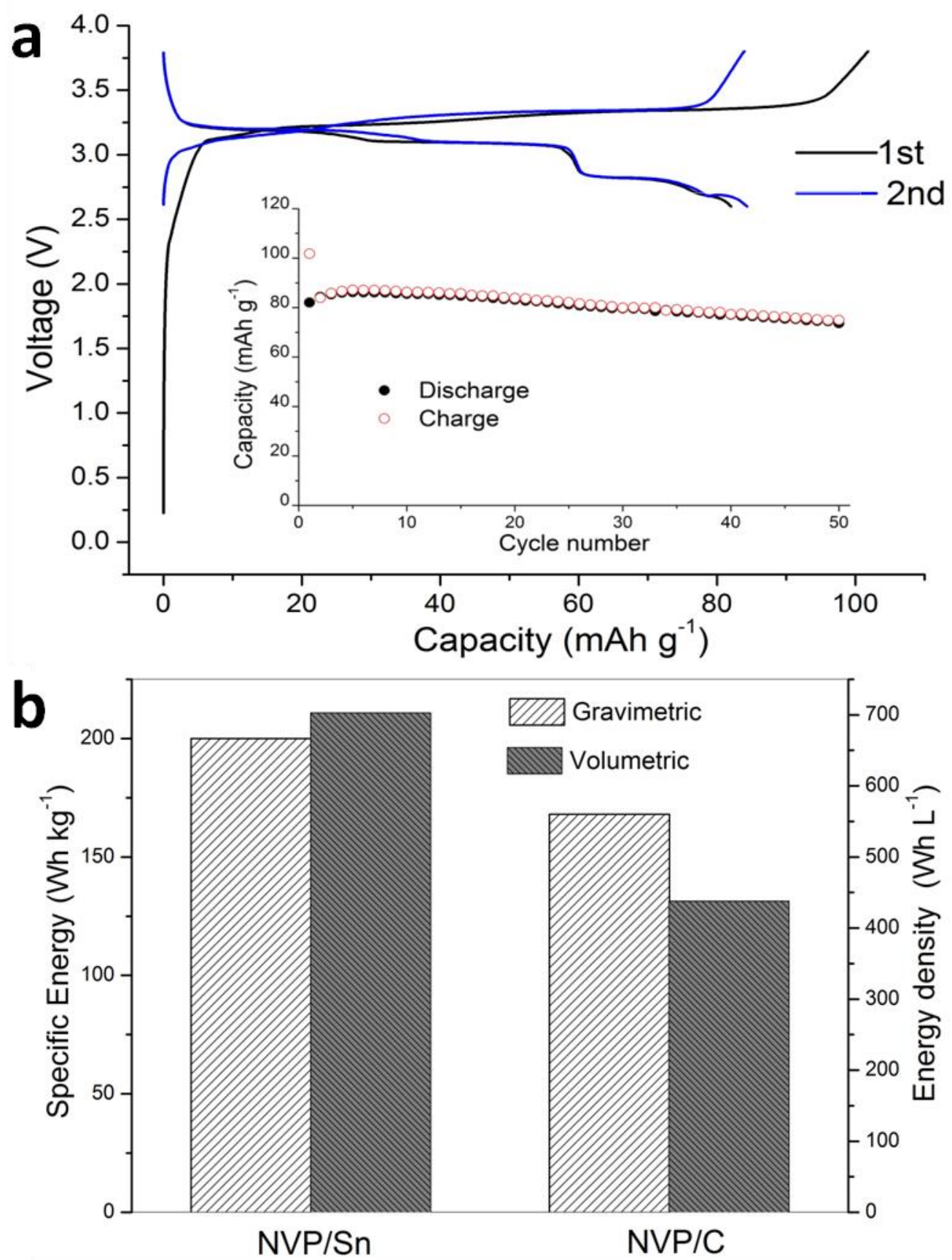

Figure 5. Performance of full cells. (a) Voltage profiles and cyclic performance (inset) of NVP/Sn; (b) Comparison of the gravimetric and volumetric energy densities of NVP/Sn and NVP/C. 
Submitted to

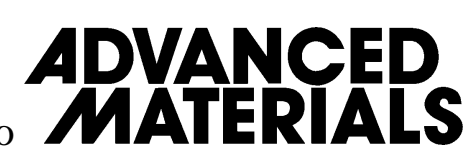

Microsized Sn presents stable cyclic performance in glyme based electrolyte, which brings $19 \%$ increase in energy density of $\mathrm{Sn} / \mathrm{Na}_{3} \mathrm{~V}_{2}\left(\mathrm{PO}_{4}\right)_{2}$ cells as compared to the cells using hard carbon anode. The $\mathrm{Na}$-Sn intermediate phases are also clarified.

Keyword: Tin, electrolyte, microsize , Na ion battery

B. Zhang, G. Rousse, D. Foix, R. Dugas, D. Alves Dalla Corte, J.M. Tarascon*

Microsized Sn as advanced anodes in glyme-based electrolyte for Na-ion batteries

ToC figure

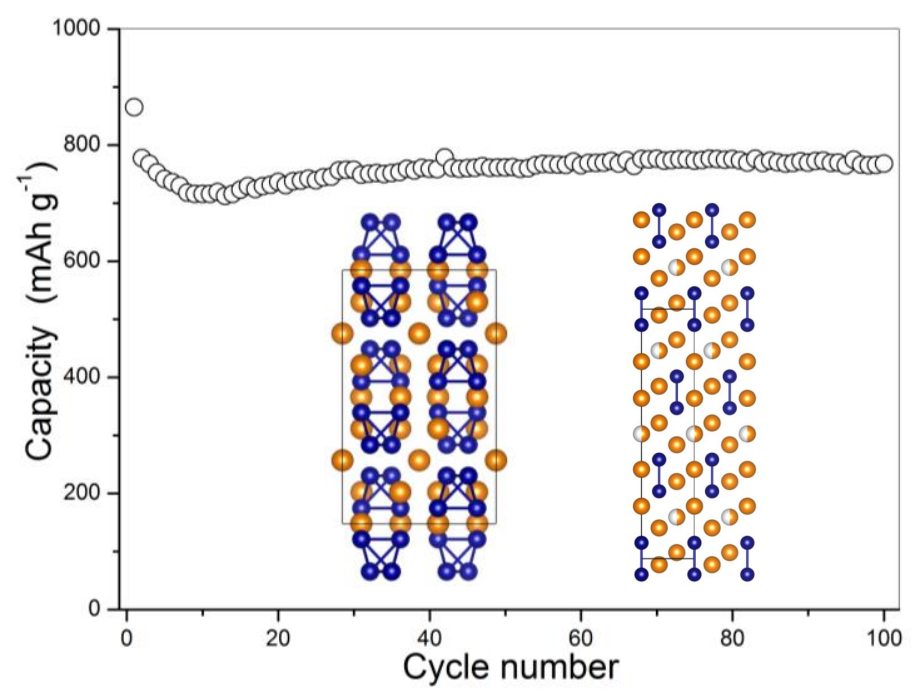




\section{Submitted to

Copyright WILEY-VCH Verlag GmbH \& Co. KGaA, 69469 Weinheim, Germany, 2013.

\section{Supporting Information}

for $A d v$. Mater., DOI: 10.1002/adma.

\section{Microsized Sn as advanced anodes in glyme-based electrolyte for Na-ion batteries}

Biao Zhang, Gwenaëlle Rousse, Dominique Foix, Romain Dugas, Daniel Alves Dalla Corte and Jean-Marie Tarascon*

Dr. B. Zhang, Prof. G. Rousse, Dr. D. Foix, Dr. R. Dugas, Dr. D. Alves Dalla Corte, Prof. J.M. Tarascon

Chimie du Solide-Energie, UMR 8260, Collège de France, 11 Place Marcelin Berthelot, 75231 Paris Cedex 05, France

E-mail: jean-marie.tarascon@ college-de-france.fr

Dr. B. Zhang, Prof. G. Rousse, Dr. D. Foix, Dr. R. Dugas, Dr. D. Alves Dalla Corte, Prof. J.M. Tarascon

Réseau sur le Stockage Electrochimique de l'Energie (RS2E), FR CNRS 3459, 80039

Amiens, France

Dr. B. Zhang, Prof. G. Rousse, Dr. D. Foix, Dr. R. Dugas, Dr. D. Alves Dalla Corte, Prof. J.M. Tarascon

ALISTORE-European Research Institute, 80039 Amiens, France

Prof. G. Rousse, Prof. J.M. Tarascon

Sorbonne Universités - UPMC Univ Paris 06, 4 place Jussieu, F-75005 Paris, France.

Dr. D. Foix

IPREM/ECP (UMR 5254), University of Pau, 2 av. Pierre Angot, 64053 Pau cedex 9,France 


\section{Submitted to \\ ADVANCED}
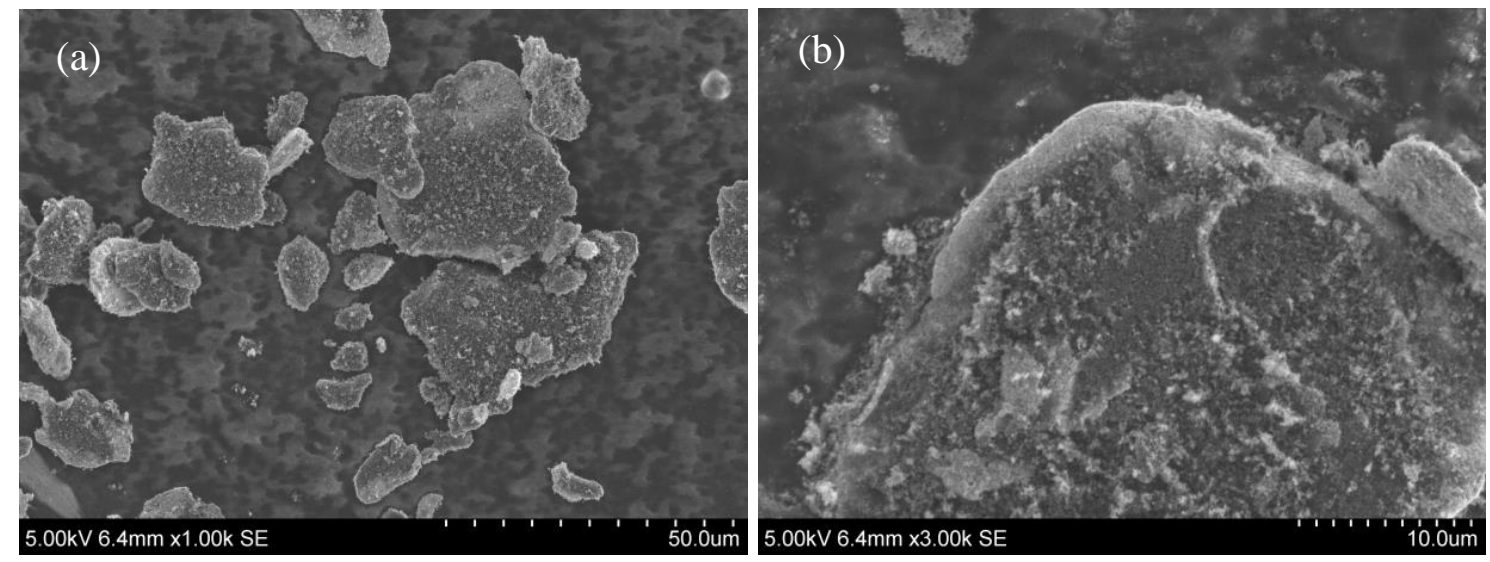

Figure S1 SEM images of Sn/Carbon SP after ball milling for 30 mins at (a) low and (b) high magnifications.
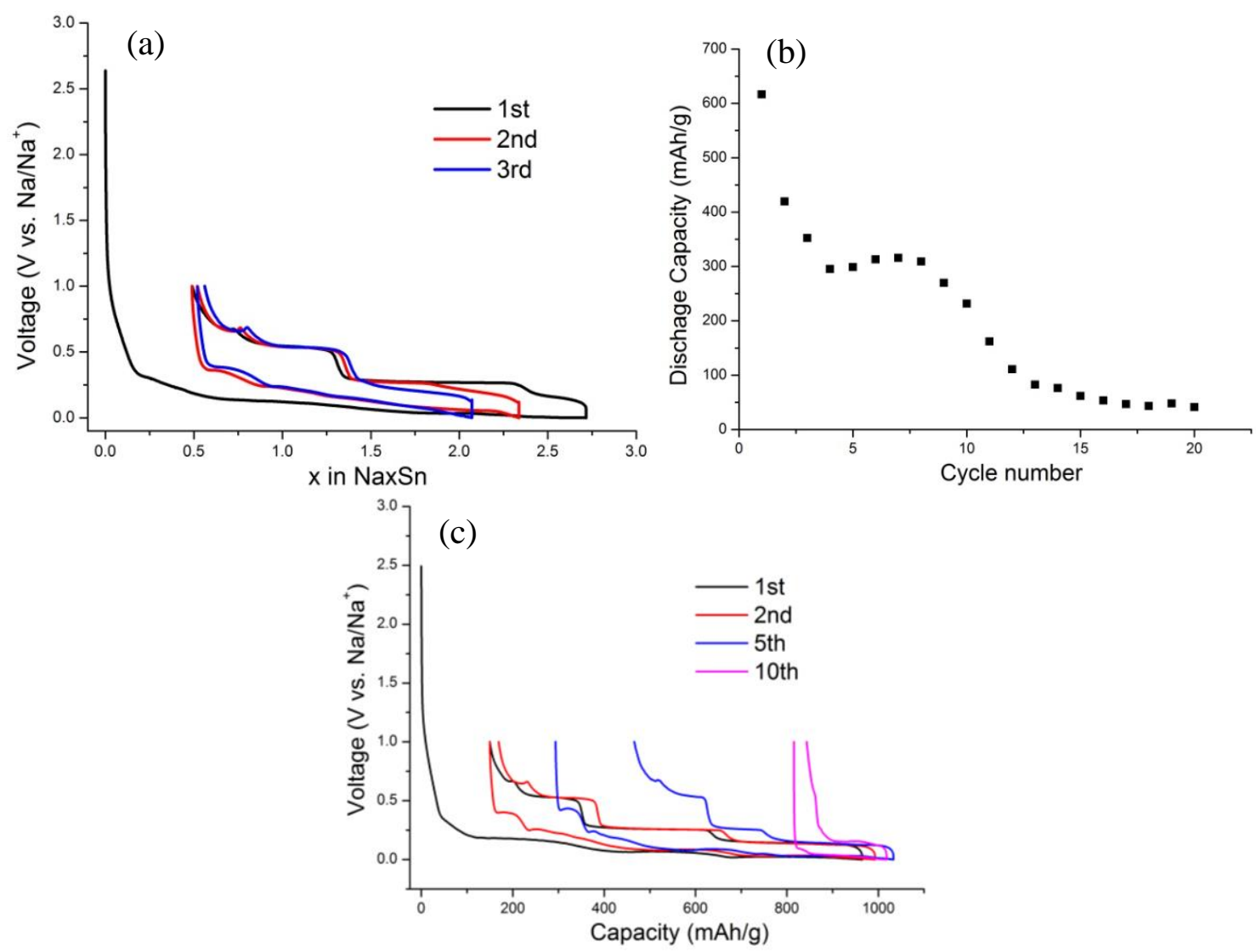

Figure S2 Electrochemical performance of $\mathrm{Sn}$ electrode in $1 \mathrm{M} \mathrm{NaPF}_{6} / \mathrm{PC}$ electrolyte with $5 \%$

FEC additives. (a) Voltage profiles and (b) cycling stability under $100 \mathrm{~mA} / \mathrm{g}$; (c) capacity at a current density of $25 \mathrm{~mA} / \mathrm{g}$. Note that reducing the current density allows fully sodiation of $\mathrm{Sn}$, which improves a lot the capacity in the first two cycles but still shows a fast capacity degradation. 


\section{ADVANCED}
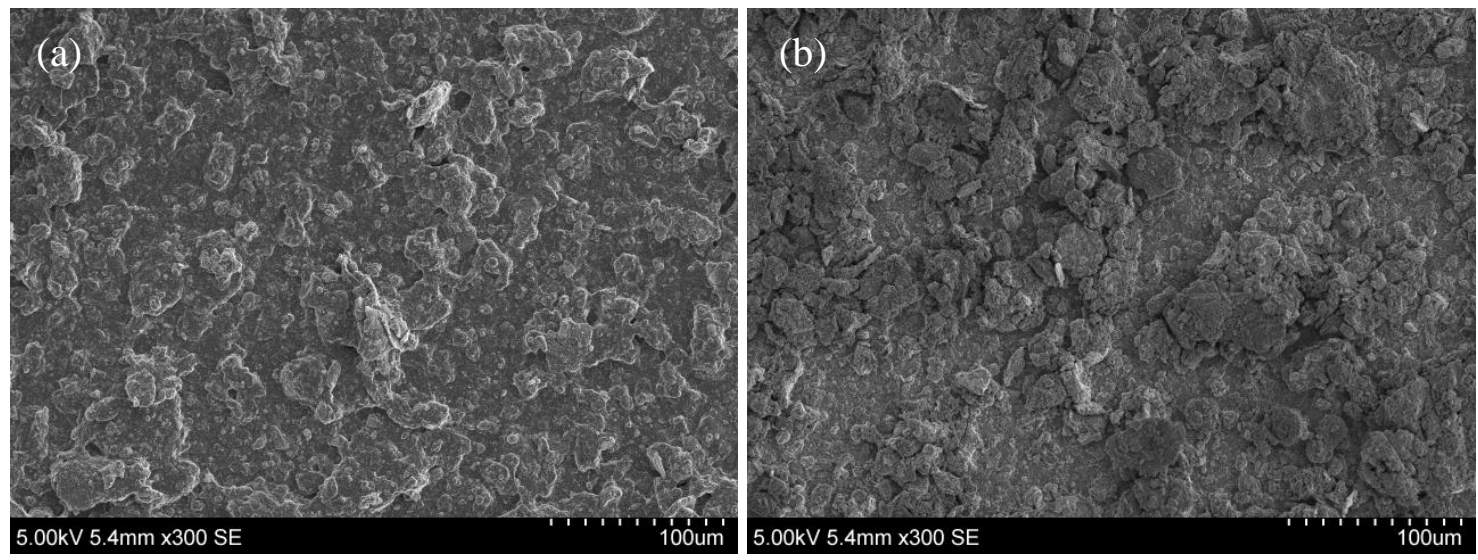

Figure S3 SEM images of Sn electrodes (a) before cycling and (b) after cycling in $1 \mathrm{M} \mathrm{NaPF}_{6}$ PC/FEC electrolyte.
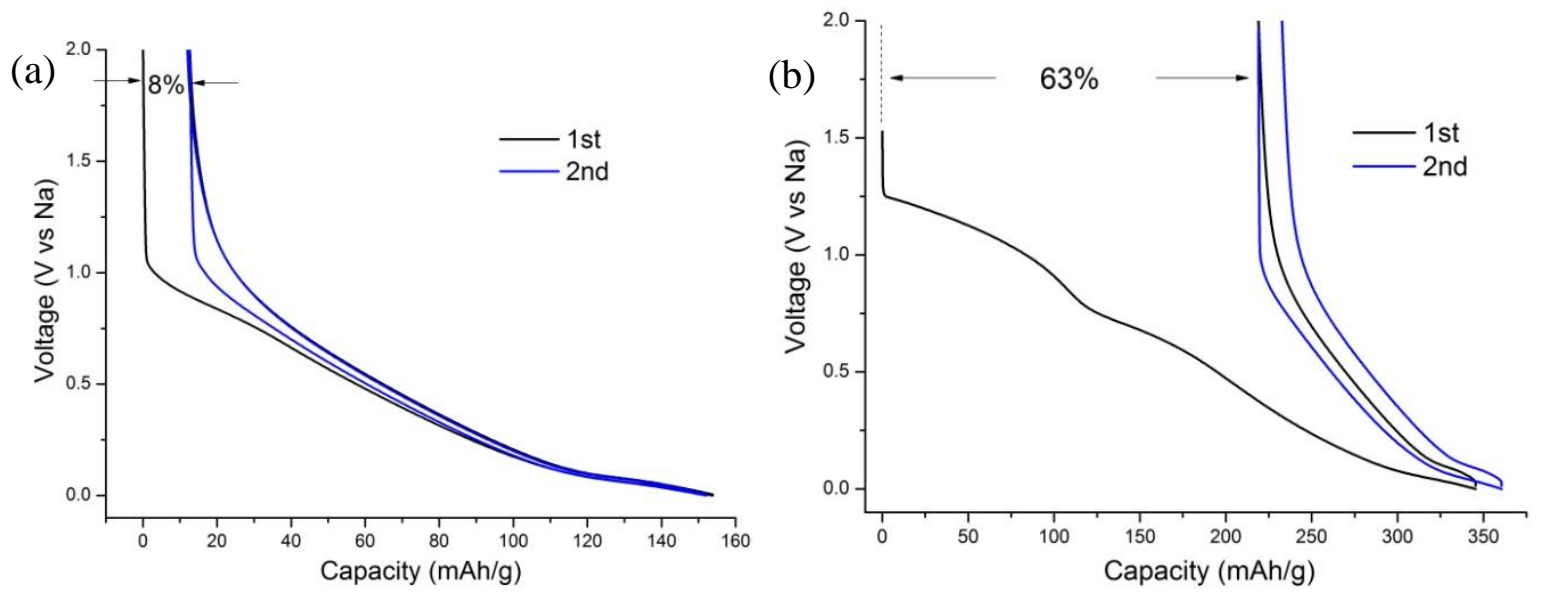

Figure S4 Voltage profiles of Csp vs $\mathrm{Na}$ in the electrolyte of (a) $1 \mathrm{M} \mathrm{NaPF}_{6}$ in DGME and (b)

$1 \mathrm{M} \mathrm{NaPF} 6$ in PC/FEC. 


\section{Submitted to \\ ADANEEDS
MATERRALIS}
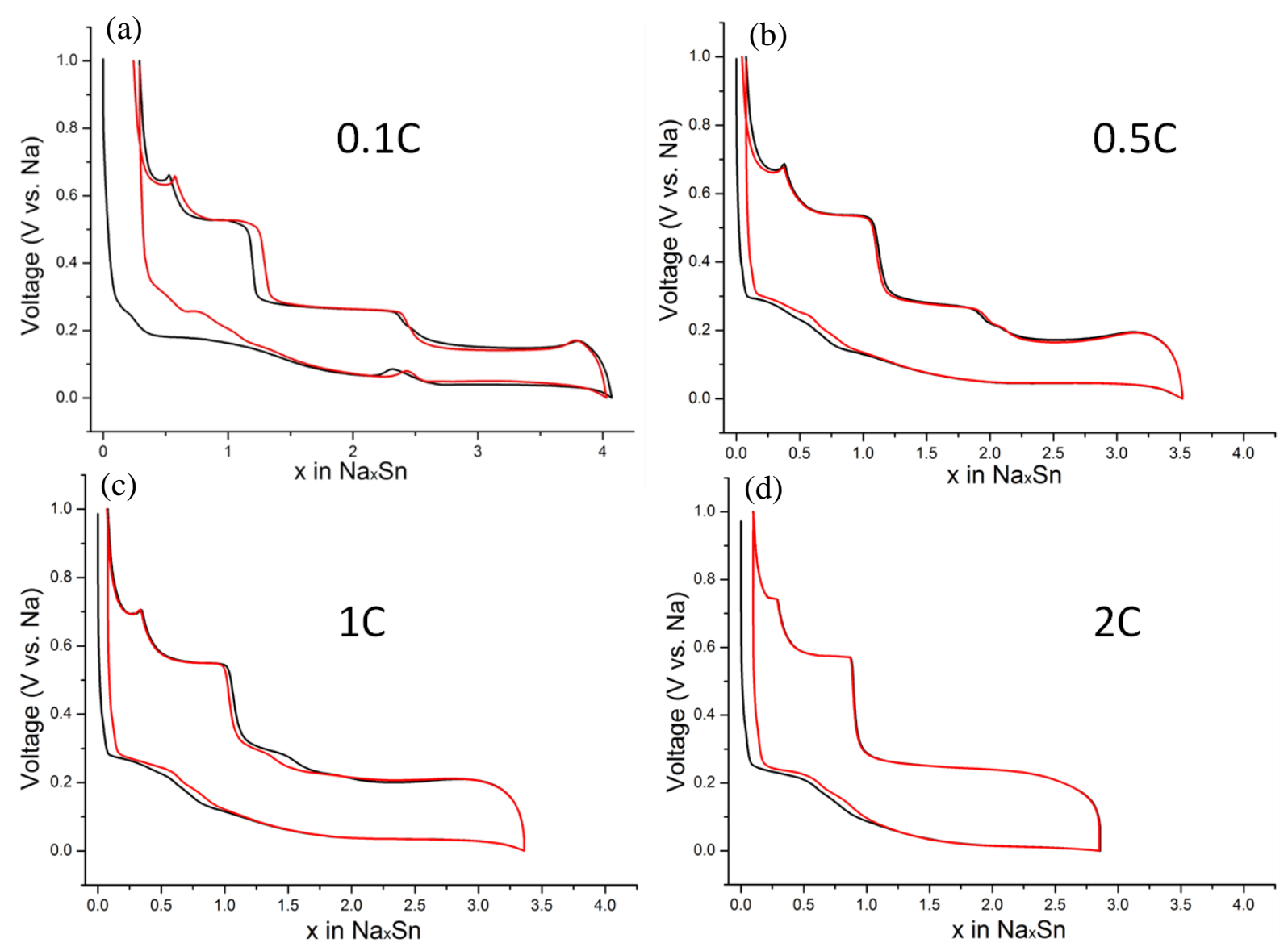

Figure S5 Voltage profiles of Sn electrode cycled under various current densities: (a) 0.1C; (b) $0.5 \mathrm{C}$; (c) $1 \mathrm{C}$ and (d) $2 \mathrm{C} .1 \mathrm{C}=847 \mathrm{~mA} / \mathrm{g}$. 


\section{ADVANCED}

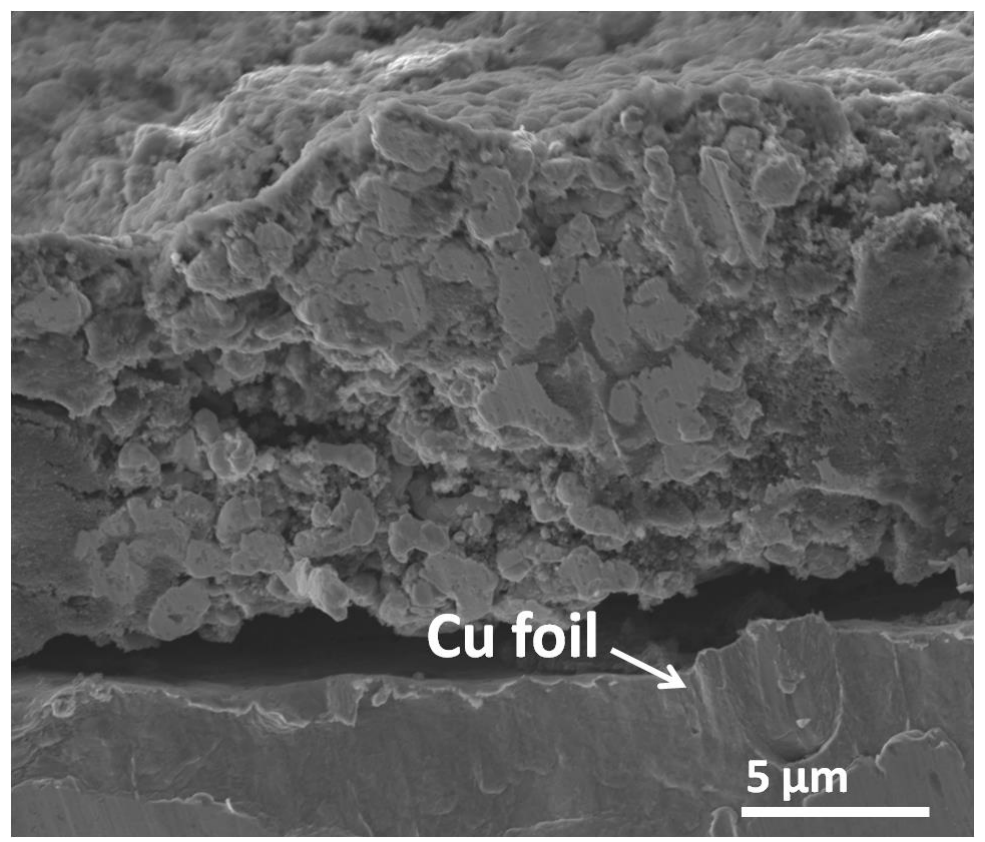

Figure S6 Cross section image of Sn electrode after cycling in DGME electrolyte. Integrity of the electrode is maintained. 


\section{Submitted to
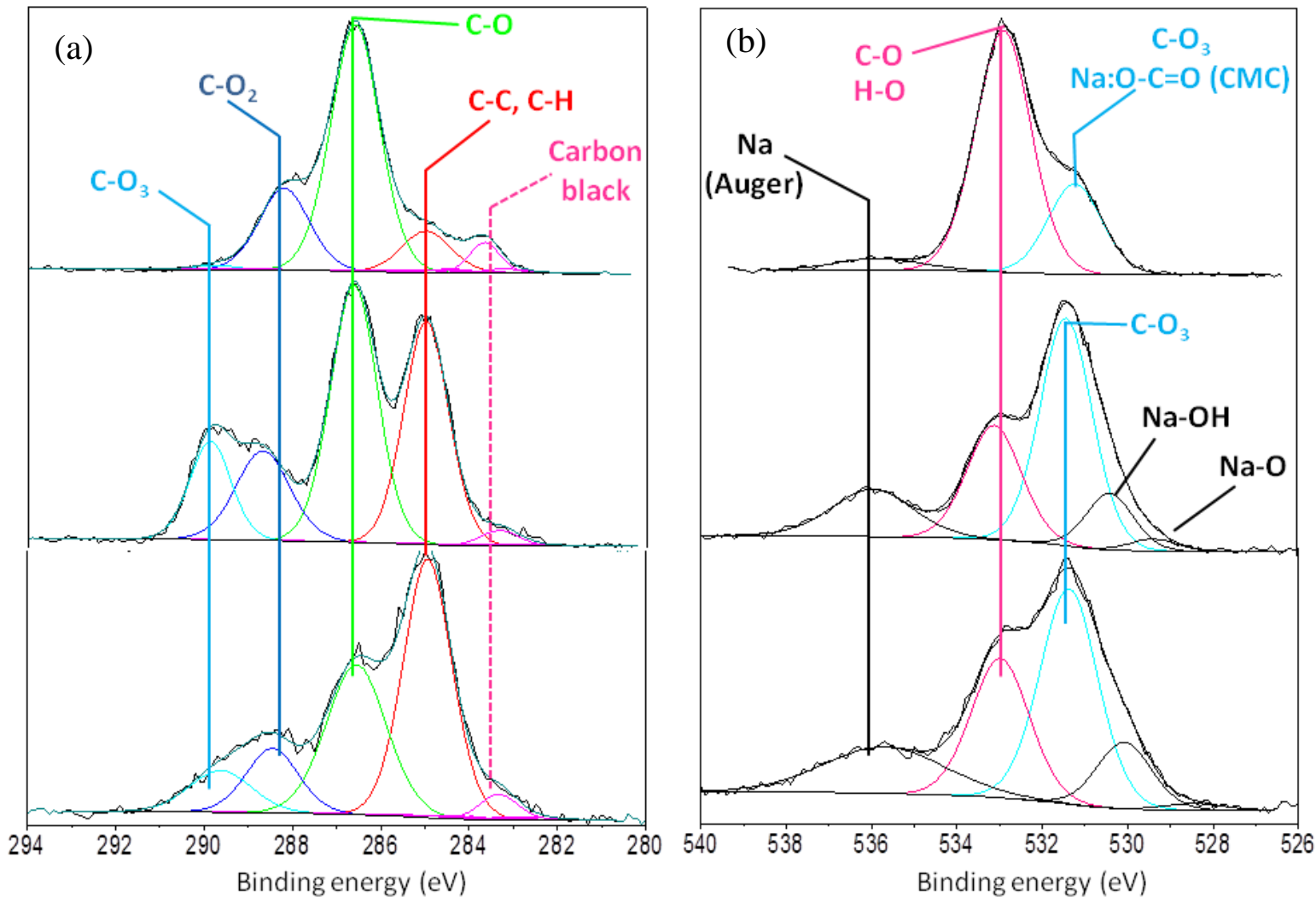

Figure S7 Comparison of (a) C1s and (b) O1s spectra for fresh electrode (top), after cycling in $1 \mathrm{M} \mathrm{NaPF}_{6} / \mathrm{DGME}$ (middle) and cycling in $1 \mathrm{M} \mathrm{NaPF}_{6} / \mathrm{PC}$ with $5 \%$ FEC (bottom). 


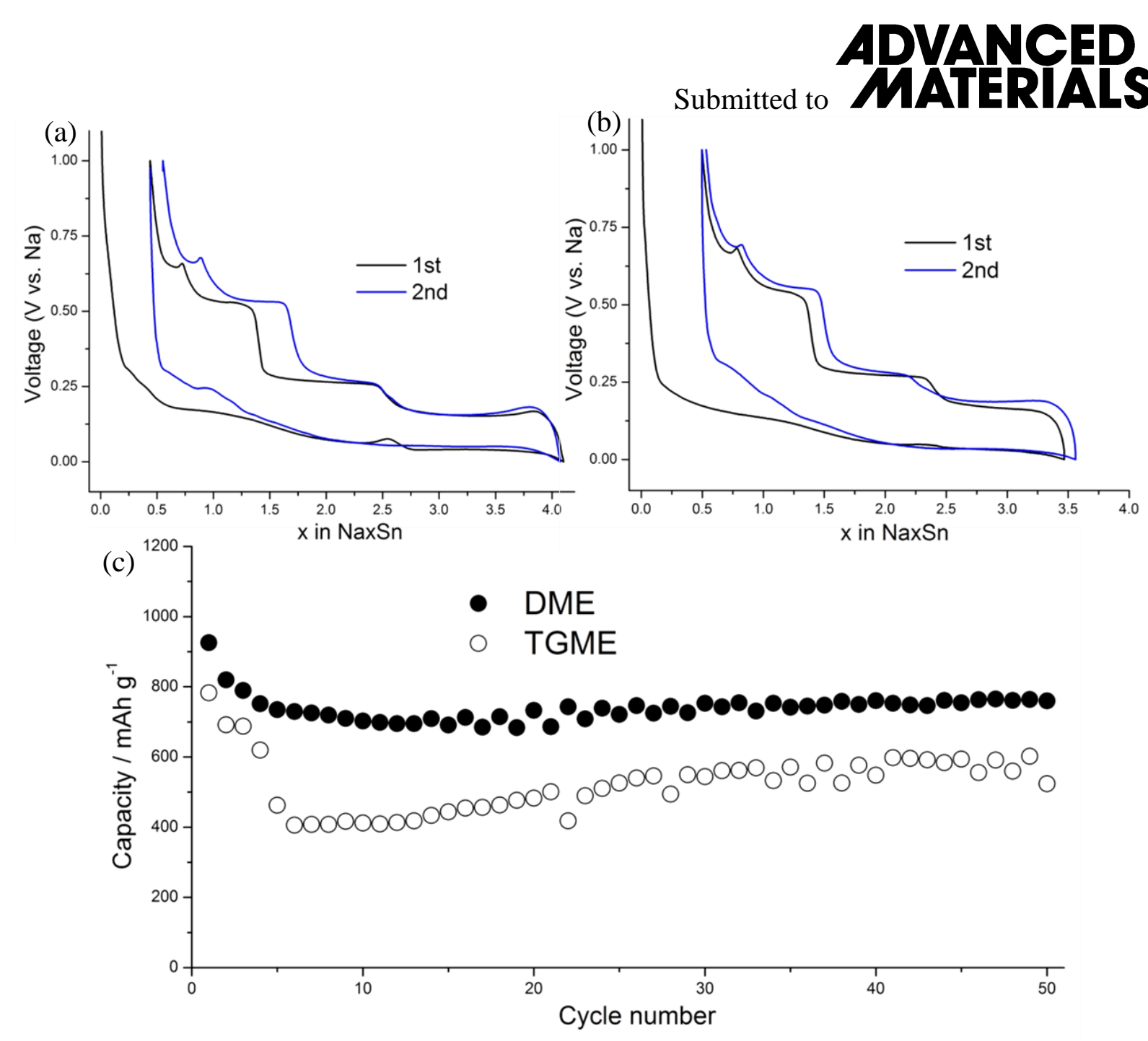

Figure S8 Voltage profiles of Sn electrode cycling in (a) $1 \mathrm{M} \mathrm{NaPF} / \mathrm{DME}$ and (b) $1 \mathrm{M}$ $\mathrm{NaPF}_{6} / \mathrm{TGME}$; (c) Cyclic stability in the two electrolytes. 


\section{Submitted to \\ ADVANCED
MATERIALS}

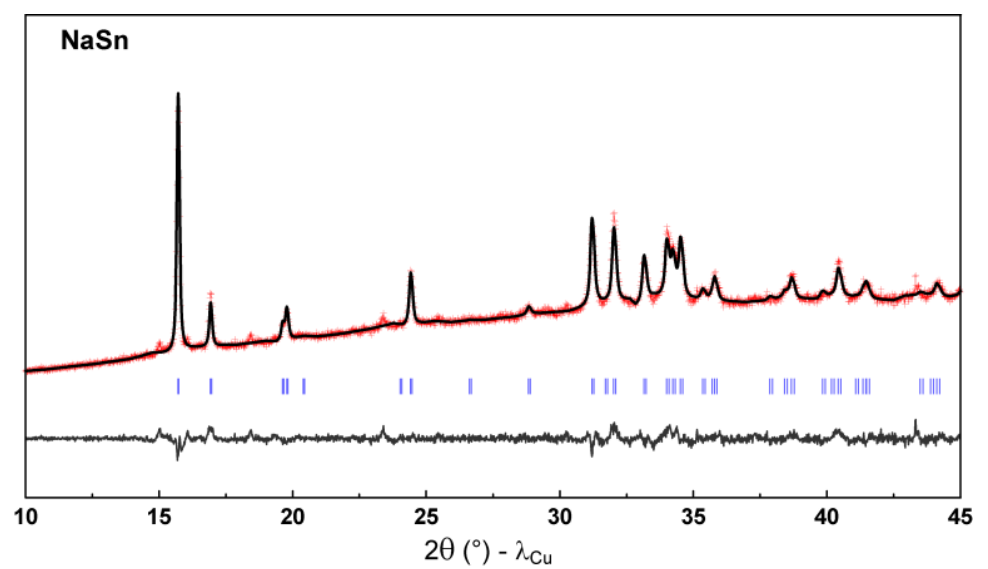

Figure S9. Rietveld refined XRD pattern of NaSn obtained electrochemically and annealed at $100{ }^{\circ} \mathrm{C}$ under Ar. The red crosses, black continuous line and bottom gray line represent the observed, calculated, and difference patterns, respectively. Vertical blue tick bars mark the Bragg reflections. 


\section{Submitted to

a

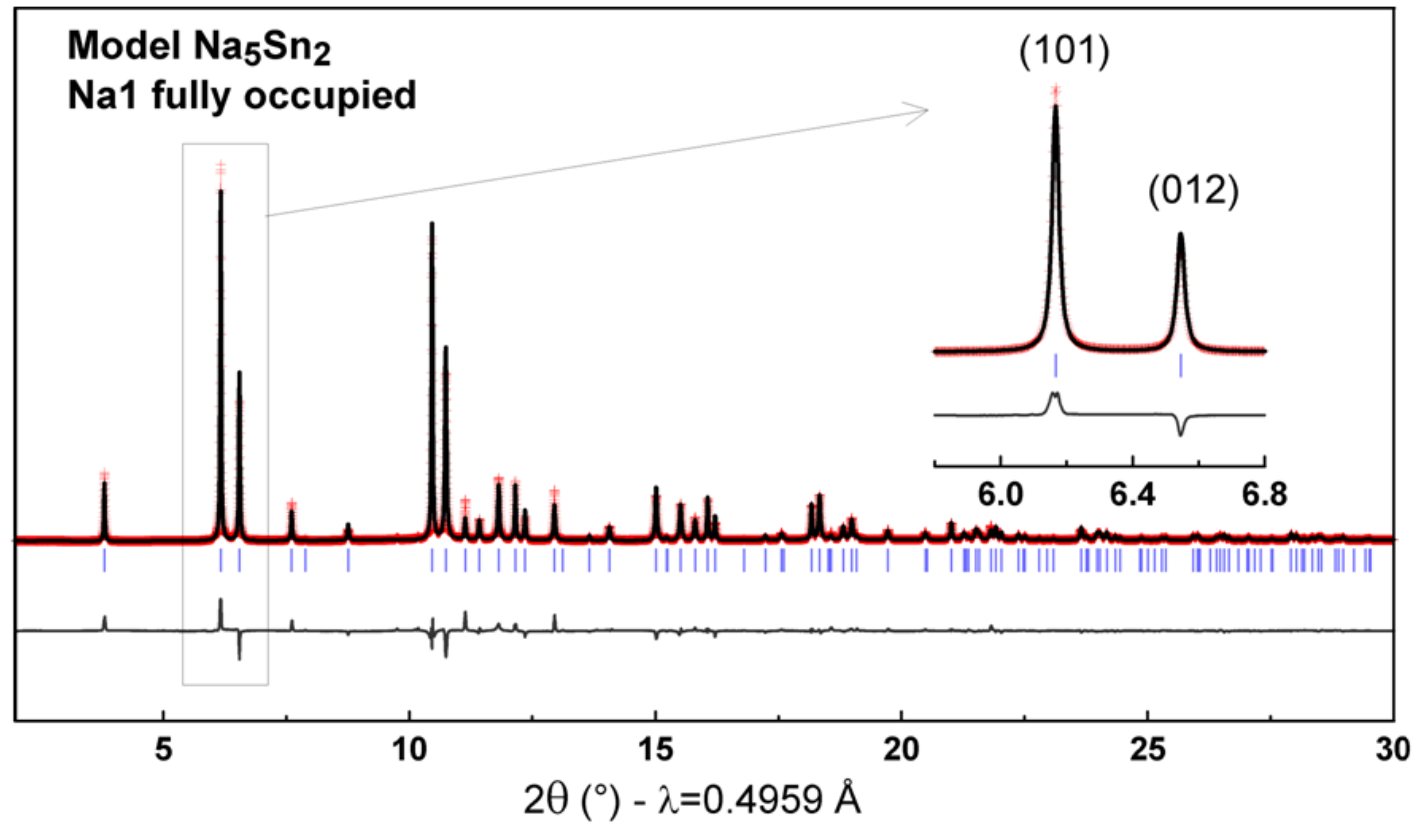

b

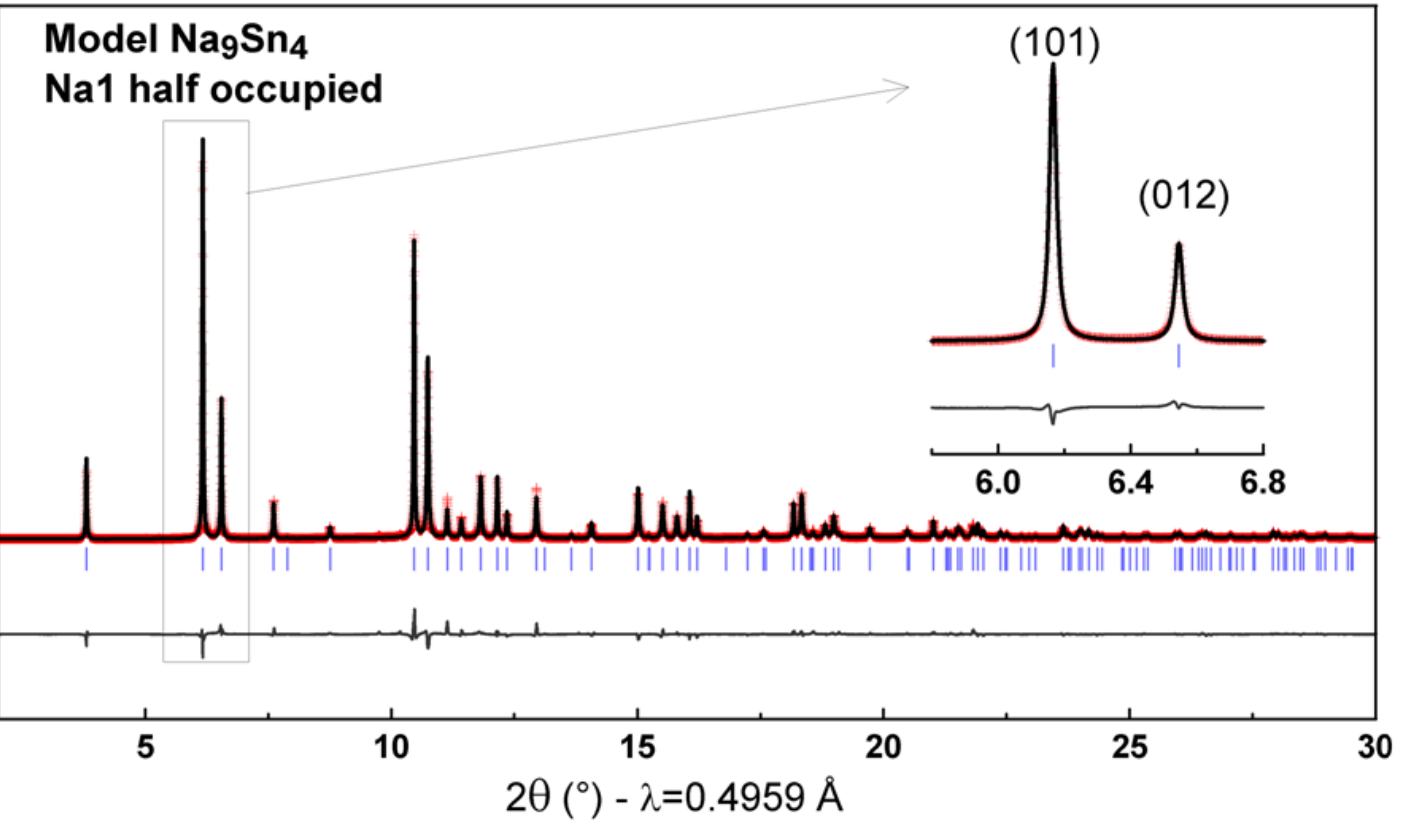

Figure S10 Rietveld refinements of the synchrotron X-ray diffraction pattern using the $\mathrm{Na}_{5} \mathrm{Sn}_{2}$ model (a) and the $\mathrm{Na}_{9} \mathrm{Sn}_{4}$ model presented in the paper. The inset highlight the improvement of the refinement on the (101) and (012) reflections when Na1 is only half occupied (chemical composition $\mathrm{Na}_{9} \mathrm{Sn}_{4}$ ). The red crosses, black continuous line and bottom gray line represent the observed, calculated, and difference patterns, respectively. Vertical blue tick bars mark the Bragg reflections arising from the $R-3 m$ space group. 

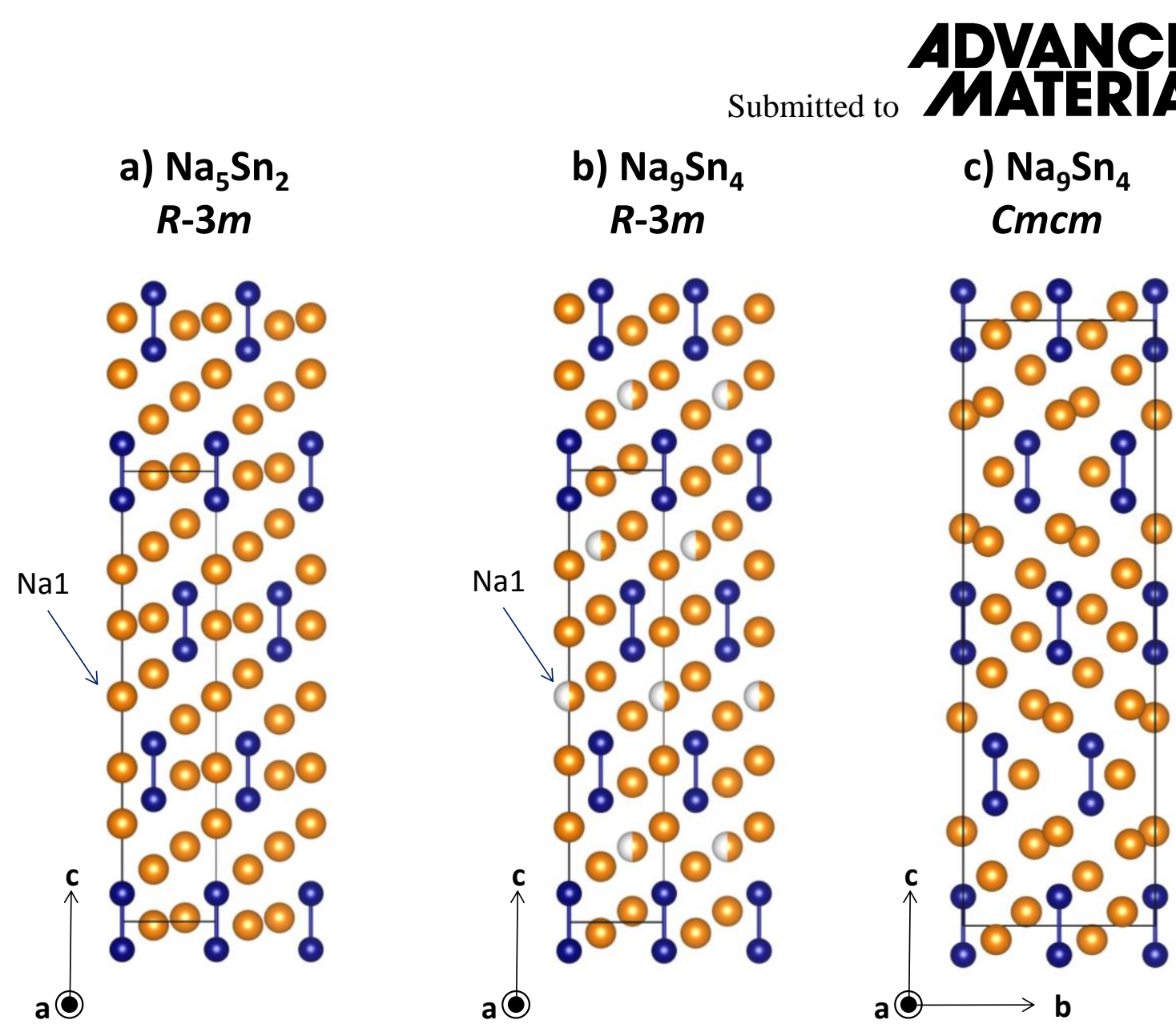

Figure S11 Structure of $\mathrm{Na}_{5} \mathrm{Sn}_{2}$ (a), and the two polymorphs of $\mathrm{Na}_{9} \mathrm{Sn}_{4}$, in $R-3 m$ (this work, b) and $\mathrm{Cmcm}$ space groups (c). $\mathrm{Na}$ and $\mathrm{Sn}$ atoms are shown as orange and dark blue balls, respectively. Vacancies on the $\mathrm{Na} 1$ for $\mathrm{Na}_{9} \mathrm{Sn}_{4}$ are colored in white. 


\section{Submitted to \\ ADVANCED}

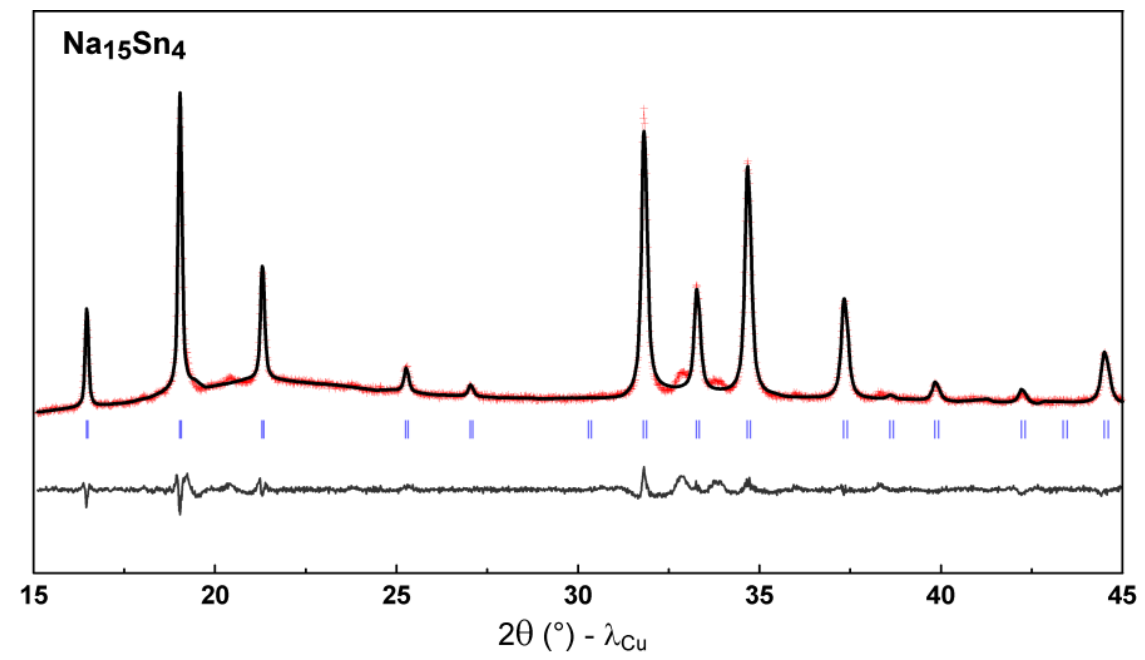

Figure S12. XRD Rietveld refinement of the $\mathrm{Na}_{15} \mathrm{Sn}_{4}$ formed by discharging to $0 \mathrm{~V}$ in the in situ cell. The red crosses, black continuous line and bottom gray line represent the observed, calculated, and difference patterns, respectively. Vertical blue tick bars mark the Bragg reflections. 


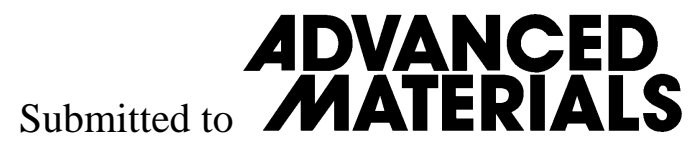
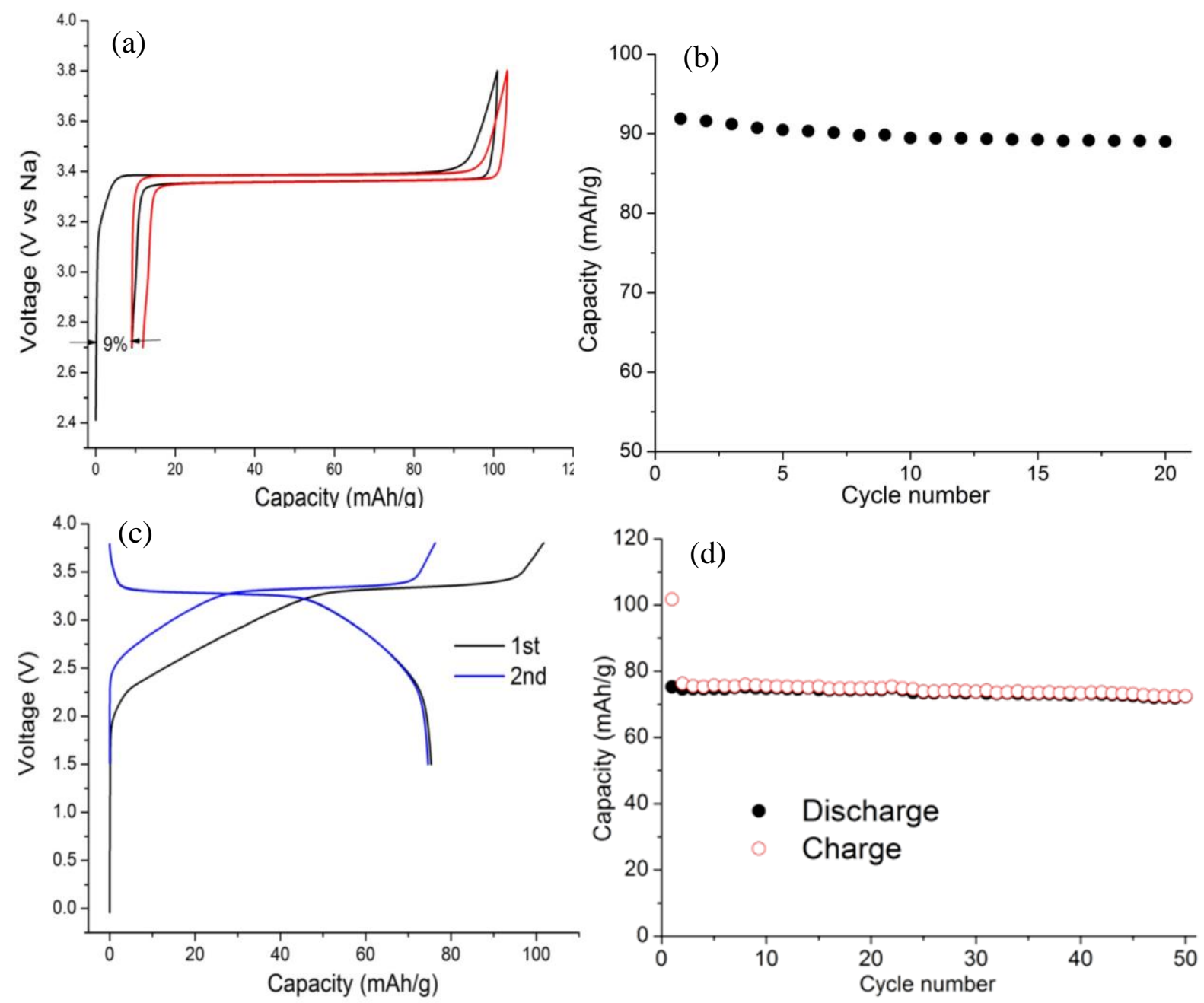

Figure S13 (a) Voltage profiles of NVP vs $\mathrm{Na}$ in $1 \mathrm{M} \mathrm{NaPF} / \mathrm{DGME}$ electrolyte and (b) the corresponding cyclic stability; (c) voltage profiles of $\mathrm{NVP} / \mathrm{C}$ full cell in $1 \mathrm{M}$ $\mathrm{NaPF}_{6} /(\mathrm{EC} / \mathrm{DMC})$ electrolyte and (d) its capacity retention in the first 50 cycles. 


\section{Submitted to

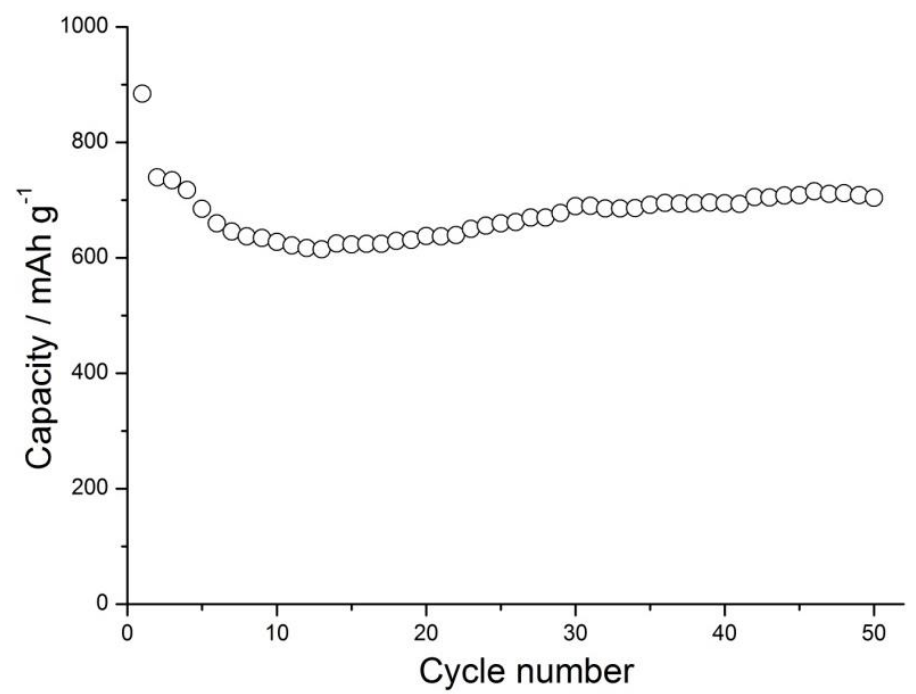

Figure S14 Cyclic performance of high loading Sn electrode $\left(4 \mathrm{mg} / \mathrm{cm}^{2}\right)$ in $1 \mathrm{M} \mathrm{NaPF}_{6} / \mathrm{DGME}$ electrolyte.

Table S1. Structural parameters for $\mathrm{Na}_{9} \mathrm{Sn}_{4}$ deduced from the Rietveld refinement of the synchrotron X-ray diffraction pattern.

\begin{tabular}{|c|c|c|c|c|c|c|}
\hline \multicolumn{7}{|c|}{$\begin{array}{c}a=5.43958(2) \AA, \mathrm{c}=22.43084(7) \AA \\
\mathrm{V}=574.788(3) \AA^{3} \text { density }=2.954 \mathrm{~g} / \mathrm{cm}^{3} \mathrm{Z}=1\end{array}$} \\
\hline Atom & Wyckoff site & $\mathbf{x}$ & $\mathbf{y}$ & $\mathbf{z}$ & Occupancy & $\mathbf{B}\left(\AA^{2}\right)$ \\
\hline $\mathrm{Na} 1$ & $3 b$ & 0 & 0 & $1 / 2$ & 0.5 & $7.20(4)$ \\
\hline $\mathrm{Na} 2$ & $6 c$ & 0 & 0 & $0.35759(10)$ & 1.0 & $7.20(4)$ \\
\hline $\mathrm{Na} 3$ & $6 c$ & 0 & 0 & $0.21034(10)$ & 1.0 & $7.20(4)$ \\
\hline $\mathrm{Sn}$ & $6 c$ & 0 & 0 & $0.06356(2)$ & 1.0 & $2.066(9)$ \\
\hline
\end{tabular}

Reliability parameters: Bragg R-factor $=5.47 \% ; \mathrm{R}_{\mathrm{F}}$ factor $=5.90 \%$ 